\title{
Quantitative assessment of atmospheric emissions of toxic heavy metals from anthropogenic sources in China: historical trend, spatial distribution, uncertainties, and control policies
}

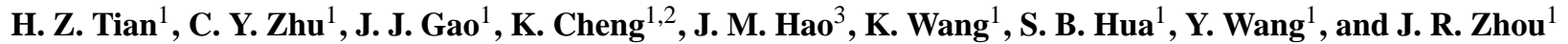 \\ ${ }^{1}$ State Key Joint Laboratory of Environmental Simulation \& Pollution Control, School of Environment, \\ Beijing Normal University, Beijing 100875, China \\ ${ }^{2}$ School of Environment, Henan Normal University, Henan Key Laboratory for Environmental Pollution Control, \\ Key Laboratory for Yellow River and Huai River Water Environment and Pollution Control, Ministry of Education, \\ Xinxiang 453007, China \\ ${ }^{3}$ State Environmental Protection Key Laboratory of Sources and Control of Air Pollution Complex, School of Environment, \\ Tsinghua University, Beijing 10084, China
}

Correspondence to: H. Z. Tian (hztian@ bnu.edu.cn)

Received: 11 March 2015 - Published in Atmos. Chem. Phys. Discuss.: 22 April 2015

Revised: 31 July 2015 - Accepted: 21 August 2015 - Published: 9 September 2015

\begin{abstract}
Anthropogenic atmospheric emissions of typical toxic heavy metals have caused worldwide concern due to their adverse effects on human health and the ecosystem. By determining the best available representation of time-varying emission factors with S-shape curves, we establish the multiyear comprehensive atmospheric emission inventories of 12 typical toxic heavy metals ( $\mathrm{Hg}, \mathrm{As}, \mathrm{Se}, \mathrm{Pb}, \mathrm{Cd}, \mathrm{Cr}, \mathrm{Ni}, \mathrm{Sb}$, $\mathrm{Mn}, \mathrm{Co}, \mathrm{Cu}$, and $\mathrm{Zn}$ ) from primary anthropogenic activities in China for the period of 1949-2012 for the first time. Further, we allocate the annual emissions of these heavy metals in 2010 at a high spatial resolution of $0.5^{\circ} \times 0.5^{\circ}$ grid with ArcGIS methodology and surrogate indexes, such as regional population and gross domestic product (GDP). Our results show that the historical emissions of $\mathrm{Hg}, \mathrm{As}, \mathrm{Se}, \mathrm{Cd}$, $\mathrm{Cr}, \mathrm{Ni}, \mathrm{Sb}, \mathrm{Mn}, \mathrm{Co}, \mathrm{Cu}$, and $\mathrm{Zn}$, during the period of 1949 2012 , increased by about 22-128 times at an annual average growth rate of 5.1-8.0\%, reaching about 526.9-22 319.6t in 2012. Nonferrous metal smelting, coal combustion of industrial boilers, brake and tyre wear, and ferrous metal smelting represent the dominant sources of heavy metal emissions. In terms of spatial variation, the majority of emissions are concentrated in relatively developed regions, especially for the northern, eastern, and southern coastal regions. In addition, because of the flourishing nonferrous metal smelting industry, several southwestern and central-southern provinces play
\end{abstract}

a prominent role in some specific toxic heavy metals emissions, like Hg in Guizhou and As in Yunnan. Finally, integrated countermeasures are proposed to minimize the final toxic heavy metals discharge on account of the current and future demand of energy-saving and pollution reduction in China.

\section{Introduction}

Heavy metals (HMs) is a general collective term which applies to the group of metals (e.g., $\mathrm{Hg}, \mathrm{Pb}, \mathrm{Cd}, \mathrm{Cr}, \mathrm{Ni}, \mathrm{Sb}, \mathrm{Mn}$, $\mathrm{Co}, \mathrm{Cu}, \mathrm{Zn}$ ) and metalloids (e.g., As, Se) with atomic density greater than $4.5 \mathrm{~g} \mathrm{~cm}^{-3}$. Although these elements are present in only trace levels in feed coals and raw materials, the huge coal consumption and enormous output of various industrial products have resulted in significant emissions of HMs into the atmosphere. As a result, the mean atmospheric concentrations of $\mathrm{As}, \mathrm{Cd}, \mathrm{Ni}$, and $\mathrm{Mn}$ are reported at $51.0 \pm 67.0$, $12.9 \pm 19.6,29.0 \pm 39.4$, and $198.8 \pm 364.4 \mathrm{ng} \mathrm{m}^{-3}$ in China respectively, which are much higher than the limit ceilings of $6.6,5,25$, and $150 \mathrm{ng} \mathrm{m}^{-3}$ for WHO guidelines, respectively (Duan and Tan, 2013). Mukherjee et al. (1998) and Song et al. (2003) indicate that various HMs can remain in the atmosphere for 5-8 days and even for 30 days when discharged 
from elevated stacks associated with fine particles. Therefore, these toxic substances can be transported for long distances before they finally settle down through wet and dry deposition into soil and aqueous systems, causing widespread adverse effects and even trans-boundary environmental pollution disputes. In particular, the International Agency for Research on Cancer (IARC) has assigned several HMs, like As and its inorganic compounds, $\mathrm{Cd}$ and its compounds, $\mathrm{Cr}$ (VI) compounds and Ni compounds, to the group of substances that are carcinogenic to humans. In addition, $\mathrm{Pb}$ and its compounds, $\mathrm{Sb}_{2} \mathrm{O}_{3}$, and $\mathrm{Co}$ along with its compounds are suspected of being probable carcinogens (IARC, 2014).

Since the 1980s, the United States, the United Kingdom, Australia and several other developed countries have begun to compile their national emission inventories of varied hazardous air pollutants (including HMs), such as the US National Emission Inventory (NEI), the UK National Atmospheric Emission Inventory (NAEI), and the Australian National Pollutant Inventory (NPI). Further, the quantitative assessments of global contamination of air by HMs from anthropogenic sources have been estimated in previous studies (Nriagu, 1979; Nriagu and Pacyna, 1988; Pacyna and Pacyna, 2001; Streets et al., 2011; Tian et al., 2014b). With the increasing environmental pollution associated with economic growth, some researchers have paid special attention to estimating China's $\mathrm{HM}$ emission inventory, especially for $\mathrm{Hg}$, which is regarded as a global pollutant (Fang et al., 2002; Streets et al., 2005; Wu et al., 2006). Streets et al. (2005) and Wu et al. (2006) developed $\mathrm{Hg}$ emission inventories from anthropogenic activities of China for the year 1999 and 1995 to 2003, respectively. A research group led by Tian established the integrated emission inventories of eight $\mathrm{HMs}(\mathrm{Hg}, \mathrm{As}$, $\mathrm{Se}, \mathrm{Pb}, \mathrm{Cd}, \mathrm{Cr}, \mathrm{Ni}$ and $\mathrm{Sb}$ ) from coal combustion or primary anthropogenic sources on the provincial level during 1980 to 2009 (Cheng et al., 2015; Tian et al., 2010, 2012a-c, 2014a, b). However, comprehensive and detailed studies on anthropogenic atmospheric emissions of 12 typical toxic HMs with highly resolved temporal and spatial distribution information in China are still quite limited. Moreover, we have little knowledge on what the past and accelerated emission levels of HMs are like from anthropogenic sources during the historical period since the founding of the People's Republic of China in 1949, to the open-poor policy (1978).

In this study, for the first time, we have evaluated the historical trend and spatial distribution characteristics by source categories and provinces of atmospheric emissions of 12 typical HMs ( $\mathrm{Hg}, \mathrm{As}, \mathrm{Se}, \mathrm{Pb}, \mathrm{Cd}, \mathrm{Cr}, \mathrm{Ni}, \mathrm{Sb}, \mathrm{Mn}, \mathrm{Co}, \mathrm{Cu}$, and $\mathrm{Zn}$ ) from primary anthropogenic activities during the period of 1949-2012. Particularly, we have attempted to determine the temporal variation profiles of emission factors for several significant sources categories (e.g., nonferrous metal smelting, ferrous metal smelting, cement production, and municipal solid waste (MSW) incineration) during the long period of 1949 to 2012, which includes the technological upgrade of the industrial process and the progress of the application rate for various air pollutant control devices (APCDs).

\section{Methodologies, data sources and key assumptions}

We estimate the atmospheric emissions of the 12 target HMs ( $\mathrm{Hg}, \mathrm{As}, \mathrm{Se}, \mathrm{Pb}, \mathrm{Cd}, \mathrm{Cr}, \mathrm{Ni}, \mathrm{Sb}, \mathrm{Mn}, \mathrm{Co}, \mathrm{Cu}$, and $\mathrm{Zn}$ ) from primary anthropogenic sources by combining the specific annual activities and dynamic emission factors by source category in this study. Table S1 in the Supplement lists the target heavy metal species and the associated emission sources. Generally, we classify all sources into two major categories: coal combustion sources and non-coal combustion sources.

\subsection{Methodology of HM emissions from coal combustion sources}

Currently, coal plays a dominant role in China's energy consumption, making up about 70 percent of its total primary energy consumption (Tian et al., 2007, 2012b). Consequently, tons of hazardous HM pollutants can be released into the atmospheric environment, although the concentration of heavy metals in Chinese coals is normally at parts per million (ppm) levels.

Atmospheric emissions of varied HMs from coal combustion are calculated by combining the provincial average concentration of each heavy metal in feed coals, the detailed coal consumption data, and the specific emission factors, which are further classified into subcategories with respect to different boiler configurations and the application rates and removal efficiencies of various APCDs. The basic formulas can be expressed as follows:

$$
\begin{aligned}
E(t)= & \sum_{i} \sum_{j} \sum_{k}\left[C_{i, j, k} \times A_{i, j, k} \times R_{i, j} \times\right. \\
& \left.\left(1-\eta_{\mathrm{PM}(i, j)}\right)\left(1-\eta_{\mathrm{SO}_{2}(i, j)}\right)\left(1-\eta_{\mathrm{NO}_{x}(i, j)}\right)\right],
\end{aligned}
$$

where $E$ is the atmospheric emissions of $\mathrm{Hg}, \mathrm{As}, \mathrm{Se}, \mathrm{Pb}, \mathrm{Cd}$, $\mathrm{Cr}, \mathrm{Ni}, \mathrm{Sb}, \mathrm{Mn}, \mathrm{Co}, \mathrm{Cu}$ and $\mathrm{Zn} ; C$ is the averaged concentration of each HM in feed coals in one province; $A$ is the amount of annual coal consumption; $R$ is the fraction of each heavy metal released with flue gas from varied coal combustion facilities; $\eta_{\mathrm{PM}}, \eta_{\mathrm{SO}_{2}}$, and $\eta_{\mathrm{NO}_{x}}$ represent the averaged fraction of one heavy metal which is removed from flue gas by the conventional $\mathrm{PM} / \mathrm{SO}_{2} / \mathrm{NO}_{x}$ emission control devices, respectively; $i$ represents the province (autonomous region or municipality); $j$ represents the subcategory emission source which is classified by different sectors of the economy and combustion facilities, as well as the installed $\mathrm{PM}, \mathrm{SO}_{2}$ and $\mathrm{NO}_{x}$ control devices (the detailed source classification can be seen in the Supplement, Table S2); $k$ represents the type of coal as consumed (raw coal, cleaned coal, briquette, and coke); and $t$ represents the calendar year. 


\subsubsection{Average concentrations of varied HMs in feed coals}

Previous studies have demonstrated that concentrations of HMs in Chinese coals vary substantially depending on the type of the feed coals and their origin, as well as the affinity of the particular element for pure coal and mineral materials (Tang et al., 2002; Ren et al., 2006).

In this study, we compile and summarize provincial-level test data of HM content in coal from published literature to date: $\mathrm{Hg}$ (879 samples), As (1018 samples), Se (472 samples), $\mathrm{Pb}$ (831 samples), Cd (616 samples), $\mathrm{Cr}$ (956 samples), Ni (863 samples), Sb (1612 samples), Mn (545 samples), Co (888 samples), $\mathrm{Cu}$ (765 samples), and Zn (828 samples), and then we calculate the average concentration of each heavy metal in coal as produced and coal as consumed on a provincial level by using bootstrap simulation and a coal transmission matrix (Tian et al., 2011a, 2013, 2014a). More details about the algorithms to determine HM concentrations in cleaned coals, briquettes and coke are given in our previous publications (Tian et al., 2010, 2012a). The brief introduction of bootstrap simulation as well as averaged concentration values of $\mathrm{Hg}, \mathrm{As}, \mathrm{Se}, \mathrm{Pb}, \mathrm{Cd}, \mathrm{Cr}, \mathrm{Ni}, \mathrm{Sb}, \mathrm{Mn}, \mathrm{Co}, \mathrm{Cu}$, and $\mathrm{Zn}$ in feed coals on the provincial level can be seen in the Supplement, Sects. S1-S2 and Table S3-S9.

\subsubsection{HM emission factors from coal combustion sources}

In this study, various coal combustion facilities are separated into five subcategories: pulverized-coal boilers, stoker-fired boilers, fluidized-bed furnaces, coke furnaces, and domestic coal-fired stoves. Therein, pulverized-coal boilers are predominant in coal-fired power plants in most of the provinces in China, representing over $85.0 \%$ of the total installed capacities. The remaining share is divided between fluidizedbed furnaces and stoker-fired boilers, which are mainly used in relatively small unit-size coal-fired power plants. Different from the thermal power plants sector, stoker-fired boilers make up a large proportion of the coal-fired industrial sector and other commercial coal-fired sectors. The release rates of HMs in flue gas from various boiler categories vary substantially due to the different combustion patterns and operating conditions, as well as their genetic physical and chemical characteristics (Reddy et al., 2005). Therefore, it is necessary to develop a detailed specification of the methods by which the coals are fed and burned in China. In this study, we have compiled the release rates of $\mathrm{Hg}, \mathrm{As}, \mathrm{Se}, \mathrm{Pb}, \mathrm{Cd}, \mathrm{Cr}$, $\mathrm{Ni}, \mathrm{Sb}, \mathrm{Mn}, \mathrm{Co}, \mathrm{Cu}$, and $\mathrm{Zn}$ for different combustion boilers from published literature (see Supplement Table S10). The arithmetic mean values of release rates of these $12 \mathrm{HMs}$ from different combustion boilers reported in the literature are adopted to calculate the final emissions (see Table 1).

Furthermore, the conventional APCDs used to reduce criteria air pollutants (e.g., $\mathrm{PM}, \mathrm{SO}_{2}$, and $\mathrm{NO}_{x}$ ) from boilers

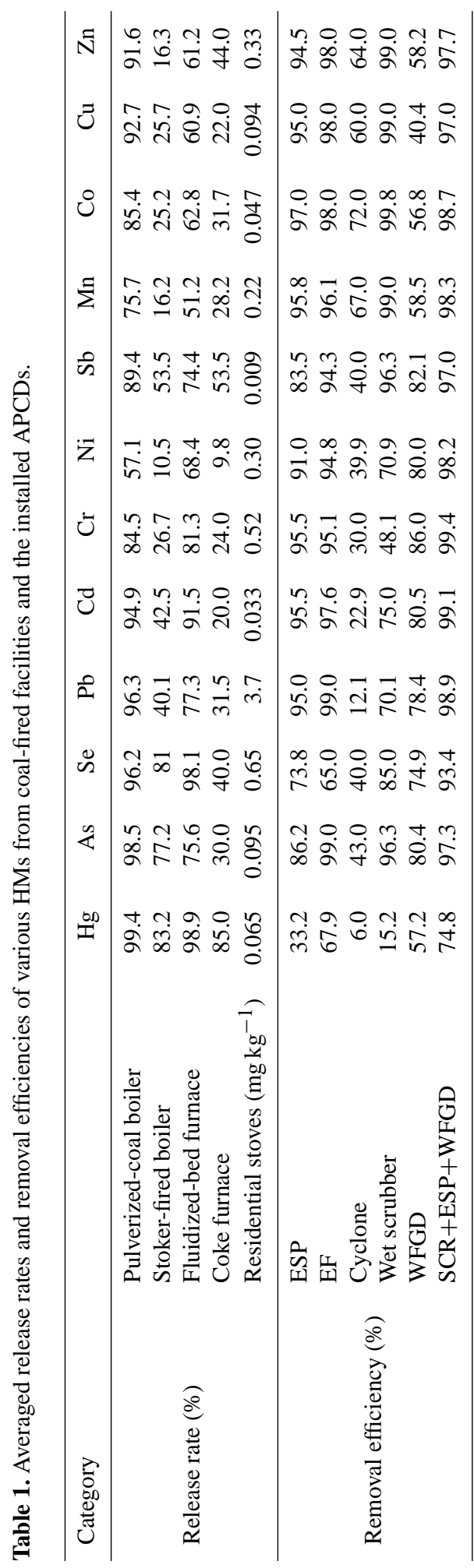

Atmos. Chem. Phys., 15, 10127-10147, 2015 
can be effective in reducing the final HM discharge from the stack flue gas. By the end of 2012, the application rate of dust collectors for removing fly ash in thermal power plants of China has been dominated by electrostatic precipitators (ESPs), with a share of approximately $94 \%$ of the total, followed by about $6 \%$ for fabric filters (FFs) or FFs plus ESPs. Meanwhile, wet flue gas desulfurization (WFGD) and selective catalytic reduction (SCR) have been increasingly used in coal-fired power plants to reduce $\mathrm{SO}_{2}$ and $\mathrm{NO}_{x}$ emissions in recent years, and the installed capacity proportion of flue gas desulfurization (FGD) and SCR have amounted to about 86.2 and $25.7 \%$ of the total capacity, respectively (MEP, 2014a, b). However, compared with coal-fired power plant boilers, there are still many small- and medium-scale industrial boilers which are equipped with cyclones and wet dust collectors to reduce fly ash emissions, and fewer FGD and de- $\mathrm{NO}_{x}$ devices have been installed to abate $\mathrm{SO}_{2}$ and $\mathrm{NO}_{x}$ emissions. In this study, we adopt the arithmetic mean values of those reported in the available literature as the average synergistic removal efficiencies by different APCD configurations, as shown in Table 1 and Supplement Table S11.

The residential sector is another important coal consumer in China. The traditional cook stoves and improved cook stoves are major combustion facilities for residential cooking and heating, both of which normally do not have any PM and $\mathrm{SO}_{2}$ control devices. There is little information about the real-world test results of HM emissions through residential coal use of China. Hence, we choose to use the averaged emission factors for coal/briquette combustion provided by AP42 (US EPA, 1993), NPI (DEA, 1999), and NAEI (UK, 2012), and the assumed emission factors of $\mathrm{Hg}, \mathrm{As}, \mathrm{Se}, \mathrm{Pb}$, $\mathrm{Cd}, \mathrm{Cr}, \mathrm{Ni}, \mathrm{Sb}, \mathrm{Mn}, \mathrm{Co}, \mathrm{Cu}$, and $\mathrm{Zn}$ by residential coal use are also listed in Table 1.

\subsection{Methodology of HM emissions from non-coal combustion sources}

HM emissions from non-coal categories are calculated as a product of annual activity data (e.g., fuel consumption, industrial product yields) and specific emission factors of varied HMs. The basic calculation can be described by the following equation:

$$
E(t)=\sum_{i} \sum_{j}\left(A_{i, j} \times \mathrm{EF}_{j}\right),
$$

where $E$ is the atmospheric emissions of each heavy metal; $A$ is the annual production yield of industrial producing processes, volume of municipal solid wastes incineration, or liquid fuel and biofuel consumption etc.; EF is the assumed average emission factors; and $j$ is the emission source classified by source subcategories (see Supplement Table S1).

Notably, atmospheric emissions of $\mathrm{Pb}$ have significantly dropped in China, as a result of unleaded gasoline introduction since the early 2000s. The proportion of lead in leaded gasoline emitted to the air is estimated at about $77 \%$ (Big- gins and Harrison, 1979) or $75 \%$ (Hassel et al., 1987), and thus this parameter is assumed to be at about $76 \%$ for the period before 2000 in this study. Consequently, for leaded gasoline used by motor vehicles in China, the total $\mathrm{Pb}$ emitted to the atmosphere is calculated according to the following equation:

$E(t)=\sum_{i}\left(0.76 \times C_{\mathrm{Pb}} \times A_{i}\right)$,

where $E(t)$ is the emissions of $\mathrm{Pb}$ from motor vehicle gasoline combustion in calendar year $t ; C_{\mathrm{Pb}}$ is the average content of lead in gasoline; and $A_{i}$ is annual gasoline consumption in one province, autonomous region or municipality $i$.

For brake and tyre wear, the atmospheric emissions of several HMs are estimated by the following equation:

$E(t)=\sum_{i} \sum_{j} \sum_{k}\left(P_{i, j} \times M_{j} \times \mathrm{EF}_{j, k} \times C_{k}\right)$,

where $E(t)$ is the atmospheric emissions of $\mathrm{As}, \mathrm{Se}, \mathrm{Pb}, \mathrm{Cd}$, $\mathrm{Cr}, \mathrm{Ni}, \mathrm{Sb}, \mathrm{Mn}, \mathrm{Co}, \mathrm{Cu}$ or $\mathrm{Zn}$ in calendar year $t ; P_{i, j}$ is the population of vehicles in category $j$ (passenger car, bus and coach, light-duty truck, and heavy-duty vehicle) in province, autonomous region or municipality $i ; M_{j}$ is the average annual mileage driven by vehicle in category $j ; \mathrm{EF}_{j, k}$ is the emission factor of TSP (total suspended particles) for brake lining or tyre $k$ by vehicle category $j$; and $C_{k}$ is the averaged concentration of each heavy metal in brake lining or tyre $k$. Relevant parameters are summarized in the Supplement Tables S12-S13.

\subsubsection{Algorithm for determination of dynamic emission factors}

Because remarkable changes in products, devices, processes as well as practices (technology improvement) have imposed positive effects on emission reductions of pollutants with the growth of the economy and the increasing awareness of environment protection, the resulting pollutant emission level at any given time is a competition between technology improvement and production growth. Consequently, one of the major challenges in this study is to develop a reasonable representation of the time-varying dynamic emission factors of HMs associated with each primary industrial activity.

Taking into consideration the updated air pollutant control technologies, and outdated enterprises that have shut down, the HM emission factors show a gradually declining trend. Generally, the patterns of technologies' diffusion across competitive markets are evident, and an S-shaped curve is a typical result when plotting the proportion of a useful service or product supplied by each major competing technology (Grübler et al., 1999). At the earliest stage of industrialization, growth rates in the removal efficiency of an air pollutant are slow as the advanced technology with high investment and operation costs is only applied in specialized niche sectors. Subsequently, along with the progress 
in technology and awareness of public environmental protection, growth rates accelerate as early commercial investments have resulted in standard-setting and compounding cost reductions, which leads to the increased application of advanced technologies for reduction in emissions of air pollutants in a wider array of settings. Eventually, growth rate in the removal efficiency will gradually approach near to zero as the potential market of optimal control technology of HM emissions is saturated. By using an S-shaped curve, both historical and future emissions of carbon aerosol and $\mathrm{Hg}$ to the atmosphere from human activities have been evaluated by Bond et al. (2007) and Streets et al. (2004, 2011). Their results show that an S-shaped curve fits historical and future trends better than polynomial or linear fits, even though it cannot account for economic shocks because of the form of monotonous smooth transitions. Therefore, S-shaped curves are applied to estimate the dynamic HM emission factors from primary industrial process sources in this study. The basic formulas can be expressed as follows:

$\mathrm{EF}_{k}(t)=\left(\mathrm{EF}_{a_{k}}-\mathrm{EF}_{b_{k}}\right) e^{\left(-\frac{\left(t-t_{0}\right)^{2}}{2 s_{k}^{2}}\right)}+\mathrm{EF}_{b_{k}}$,

where $\mathrm{EF}_{k}(t)$ is the emission factor for process $k$ in calendar year $t ; \mathrm{EF}_{a_{k}}$ represents the emission level for process $k$ pre$1900 ; \mathrm{EF}_{b_{k}}$ is the best emission factor achieved in China for process $k$ at present; $s_{k}$ is the shape parameter of the curve for process $k$ (like the SD); and $t_{0}$ is the time at which the technology transition begins (pre-1900).

Based on the above method, we build the dynamic representation of $\mathrm{HM}$ emission factors to reflect the transition from uncontrolled processes pre-1900 to the relatively highefficiency abatement processes in 2012. Parameters for some of these transitions are discussed throughout the paper, and are summarized in the Supplement, Table S14. Actually, on the basis of Eq. (5), the specific values of the shape parameter of the curve $(s)$ can be determined when we obtain the definite values of pre-1900 unabated emission factors and the best emission factor achieved at present for each industrial process in China. In addition, several values of $s$ are cited from Street et al. (2011) if only limited information about the emission level for certain processes can be gained.

\subsubsection{Dynamic HM emission factors of nonferrous metal smelting}

By 2010, bath smelting (e.g., Ausmelt smelting, Isa smelting), flash smelting, and imperial smelting process (ISP) represent the three most commonly used techniques for copper smelting, for about 52, 34, and $10 \%$ of Chinese copper production, respectively. For lead smelting, sintering plus a blast furnace technique (traditional technique) and bath smelting (e.g., oxygen side blowing, oxygen bottom blowing) plus a blast furnace technique (advanced technique) are the two most commonly used techniques in China, accounting for about 48 and $47 \%$ of lead production, respectively. With re- spect to zinc smelting, hydrometallurgy is the predominant technique in China, for about $77 \%$ of the zinc production capacity. The remaining share is divided among vertical retort (VR) pyrometallurgy $(\sim 10 \%)$, imperial smelting process (ISP) pyrometallurgy $(\sim 7 \%)$, and other pyrometallurgy $(\sim 6 \%)$. Especially, VR pyrometallurgy is regarded as an outdated technique which is mandated to be shut down gradually and will be totally eliminated in the near future.

Because of limited information and lack of field experimental tests on HM emissions in these source categories in China, some emission factors for this source category are cited from published literature, with only nationally averaged levels. Streets et al. (2011) indicate that China, eastern Europe and the former USSR can be regarded as a uniform region with similar levels of technology development, whose emission factor trajectories are identical. Therefore, we presume the emission factors of HMs with higher abatement implementation in eastern Europe, Caucasus and central Asian countries are equivalent to those in China for the same calendar year (see Fig. 1a). Based on the above assumptions and default abatement efficiencies of HMs in nonferrous metal smelting sectors (EEA, 2013), as well as other specific emission factors of HMs from published literature to date (Nriagu, 1979; Pacyna, 1984; Pacyna and Pacyna, 2001), the unabated emission factors are determined (see Supplement Tables S15-S16).

Presently, compared to primary smelting of $\mathrm{Cu}, \mathrm{Pb}$ and $\mathrm{Zn}$, there is much less information about emission factors of HMs for secondary metal smelting of $\mathrm{Cu}, \mathrm{Pb}$ and $\mathrm{Zn}$ and other nonferrous metals ( $\mathrm{Al}, \mathrm{Ni}$ and $\mathrm{Sb}$ ) smelting from the published literature. Hence, it is much more difficult to estimate the time-varying dynamic emission factors of HMs from the above sectors by the use of S-shaped curves due to a lack of necessary baseline information. We presume that the average emission factors for secondary metal $(\mathrm{Cu}, \mathrm{Pb}$ and $\mathrm{Zn)} \mathrm{smelting,} \mathrm{aluminum} \mathrm{smelting,} \mathrm{antimony} \mathrm{smelting,}$ and nickel smelting remain unchanged before the year 1996, at which the Emission Standard of Pollutants for Industrial Kiln and Furnace was first issued in China. We also presume that the average emission factors of HMs from secondary metal smelting and other nonferrous metal smelting for developing countries, referred to in Pacyna and Pacyna's report (2001) and eastern Europe, Caucasus and central Asian countries with limited abatement referred to in the EEA Guidebook (EEA, 2009; S. V. Kakareka, personal communication, 2008), as well as the United Kingdom applied in the NAEI emission factors database pre-1990 (UK, 1995), are reasonable for China before the year 1996. Subsequently, atmospheric emission factors of HMs from the industry of nonferrous metals in China decrease gradually with the implementation of tightened emission limits regulated by the gradually stricter Emission Standards of Pollutants from nonferrous metals industry (e.g., GB 9078-1996, GB 25465-2010, GB 25466-2010, GB 25467-2010). 

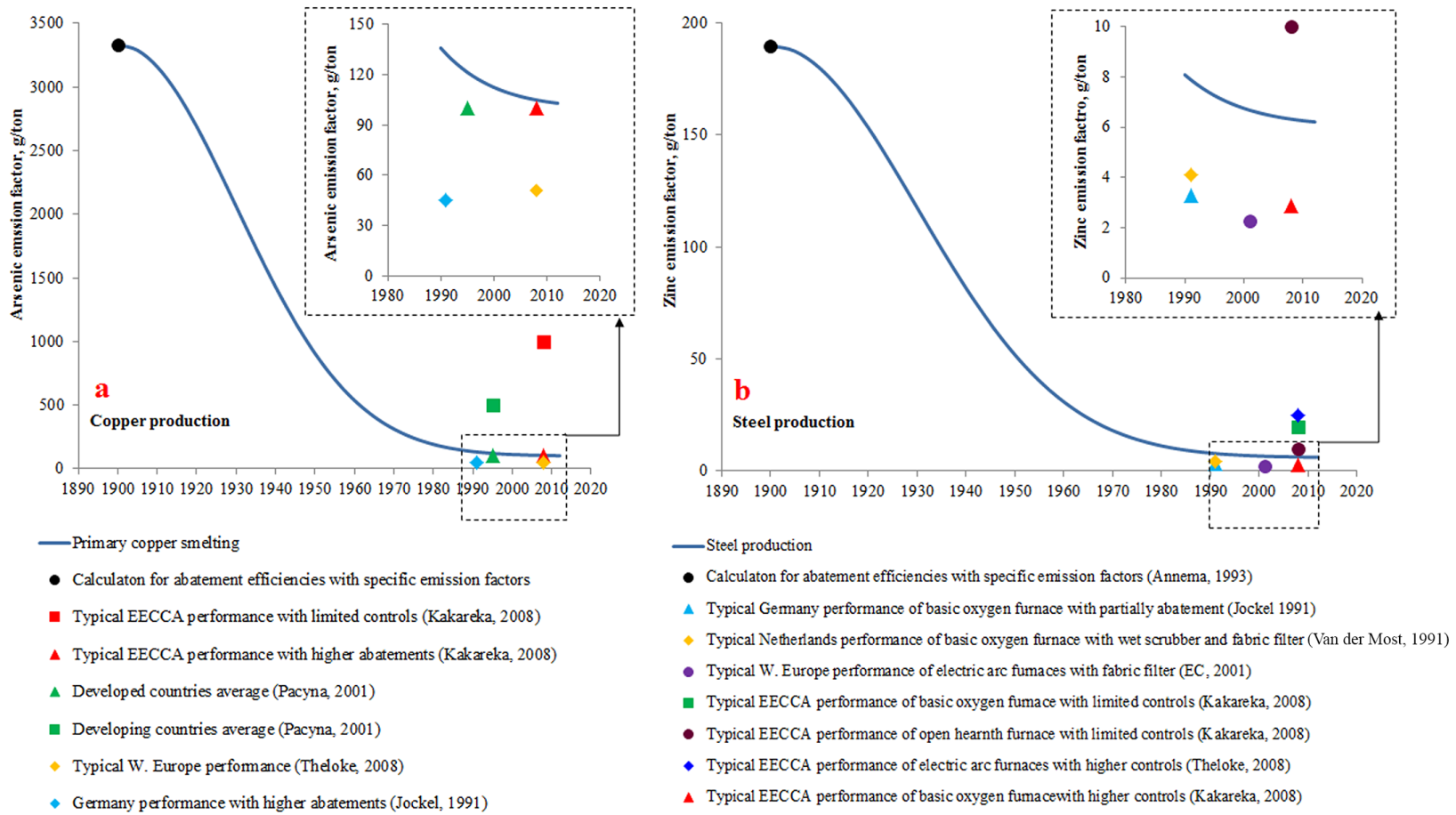

Figure 1. Time variation of arsenic emission factors for copper production and zinc emission factors for steel production in China (an example).

With respect to gold smelting (large-scale) and mercury mining industries, the time-varying $\mathrm{Hg}$ emission factors from these two subcategories are determined by referring to studies carried out by Feng (2005), Streets et al. (2005, 2011), Pacyna and Pacyna (2006) and Pirrone et al. (2010). Specific emission factors of HMs from nonferrous metal smelting sectors can be seen in the Supplement, Table S16.

\subsubsection{Dynamic HM emission factors of ferrous metal smelting}

Currently, the blast furnace is the primary technique for pig iron production in China. For steel production, there are two main routes: (1) "ore BF-BOF steel-making route" based on blast furnace $(\mathrm{BF})$ and basic oxygen furnace (BOF) techniques, and (2) "scrap-EAF steel-making route" based on an electric arc furnace (EAF) technique, using steel scrap or sponge iron as basic raw materials (Zhang and Wang, 2008). In spite of the environmental friendly nature of EAF and its flexibility to produce a variety of value-added grades of steel, the share of electric furnace steel in Chinese output of crude steel only accounts for about $8.9 \%$ in 2012, mainly due to the shortness of steel scrap resources in China (CISA, 2013).

Comparing the national emission standard of air pollutants for the iron smelting industry in China with those in certain European Union countries (e.g., United Kingdom, Germany, Netherlands, Austria), we choose to use the emission factors of HMs for the iron smelting industry obtained from the emission factors database of NAEI in 2000 as the national average emission factors for iron smelting of China in 2015. This is mainly because the PM emission limit of existing facilities for iron smelting of China in $2015\left(20 \mathrm{mg} \mathrm{m}^{-3}\right)$ is approximately comparable to that of European Union countries in the early 2000s (IRIS, 2005; MEP, 2012). With respect to steel smelting, the emission factors of HMs with higher abatement in eastern Europe, Caucasus and central Asian countries are chosen as the national average emission factors of this sector in China in the same calendar year (see Fig. 1b). The unabated emission factors of HMs for pig iron and steel production are determined by using a similar method to the one discussed above for the nonferrous metal smelting industry. Please see the Supplement, Tables S16 and S17 for more details about specific emission factors.

\subsubsection{Dynamic HM emission factors of non-metallic mineral manufacturing}

Cement, glass, and brick manufacturing are the major mineral commodity industries. During the manufacturing process, various HMs emitted from raw materials as vapor and feed fuels associated with fine particulate matter are emitted from the kiln system at high temperatures.

Currently, the new dry rotary kiln process is the dominant technology in cement manufacturing factories of China, representing over $92 \%$ of the total national cement output. The emission ceilings of air pollutants for cement, glass or brick 
manufacturing specified in the present standards of China (e.g., GB 4915-2013, GB 26453-2011, GB 29620-2013) are less stringent compared with those of developed countries (see Supplement Table S18). By contrasting the emission limits of air pollutants from non-metallic minerals (cement, glass, and brick) manufacturing between China and developed countries, we presume the best emission factors of air pollutants achieved in China today are approximately identical to the average emission factors of developed countries at the end of the 1990s. With respect to cement production, the unabated emission factors of HMs can be obtained from the Web Factor Information Retrieval System (WebFIRE) (US EPA, 2012). Moreover, the average emission factors for glass and brick manufacturing are assumed to remain unchanged since pre-1996. Subsequently, atmospheric emission factors of HMs from these two sub-source categories decrease gradually with the implementation of gradually tightened emission limits from the above-mentioned Emission Standards of Pollutants from the non-metallic mineral manufacturing industry. Specific emission factors of various HMs from nonmetallic mineral manufacturing can be seen in the Supplement, Table S16.

\subsubsection{HM emission factors of biomass burning}

China is the biggest developing country in the world. The rural population still accounted for nearly $47.4 \%$ of the total population in 2012 (NBS, 2013a), and it has had a long history of using agricultural residues and firewood to satisfy household energy demands for cooking and heating. Recently, crop residues have become more commonly burned in open fields during the harvest season. Abundant gaseous and particulate pollutants emitted by open biomass burning have caused severe regional air pollution and contributed to worsening of haze events in central and eastern China (Cheng et al., 2014; Li et al., 2014).

In this paper, a total mass of ten crop straws burned is calculated based on the method discussed in previous studies by Tian et al. (2011b) and Lu et al. (2011), including paddy, wheat, maize, other grains, legumes, tubers, cotton, oil plants, fiber crops, and sugar crops. Because of quite limited field test data about HM emission characteristics from crop straw for household use and firewood for open burning, we presume HM emission factors from biofuel for open burning are equal to those for household use. It is acknowledged that this simple assumption may introduce additional uncertainties, and thus relatively large uncertainty ranges for HM emission factors of biofuel combustion are applied in the analysis, which merits substantial investigation in the future. The average emission factors of HMs from these ten crop straws and firewood are summarized in the Supplement, Table S16.

\subsubsection{HM emission factors of liquid fuels combustion}

Besides major conventional pollutants ( $\mathrm{PM}, \mathrm{SO}_{2}$, and $\mathrm{NO}_{x}$ ), liquid fuel combustion generates emissions of potentially toxic HMs. Here, the liquid fuels are sorted into crude oil, fuel oil, kerosene, diesel, and gasoline.

Historically, leaded gasoline combustion by vehicles has been recognized as the most significant contributor for the increase in lead level in human blood (Robbins et al., 2010). Leaded gasoline has been forced out of the market place in China since 1 July 2000 due to the adverse health effects on the neurologic and/or hematologic systems (Xu et al., 2012). Compared to the $\mathrm{Pb}$ content limits of $0.64 \mathrm{~g} \mathrm{~L}^{-1}$ (GB 48464, 1949-1990), and 0.35 $\mathrm{g} \mathrm{L}^{-1}$ (GB 484-89, 1991-2000) in leaded gasoline, the average lead content in unleaded gasoline is regulated at less than $0.005 \mathrm{~g} \mathrm{~L}^{-1}$ (GB 17930-1999, 2001-2012). Consequently, $C_{\mathrm{Pb}}$ in Eq. (3) is chosen to be $0.64,0.35$, and $0.005 \mathrm{~g} \mathrm{~L}^{-1}$ for the three corresponding periods, respectively (Qin, 2010). All the other average emission factors of HMs from each type of liquid fuel are summarized in the Supplement, Table S16.

\subsubsection{Dynamic HM emission factors of municipal solid waste incineration}

For municipal solid waste (MSW) incineration, emission characteristics of HMs significantly depend on the concentration of metals in the feed wastes, the performance of installed APCDs, combustion temperatures, as well as composition of the gas stream (Chang et al., 2000).

Presently, stoke grate and fluidized-bed combustion are the major MSW incineration technologies being used in China. Because of relatively high costs and the heat content requirement for the feed MSW (>6000-6500 $\mathrm{kJ} \mathrm{kg}^{-1}$, or supplementary fuel is necessary), stoke grate incinerators are typically used in eastern coastal areas, especially in the economically more developed cities (Nie, 2008), taking a share of over $58 \%$ by the end of 2010 (Cheng and $\mathrm{Hu}, 2010$; Tian et al., 2012d). Fluidized-bed incinerators, in contrast, are mainly adopted in the eastern small and mid-sized cities, as well as the large cities in the middle and western parts of China, taking a relatively small proportion, mainly due to the lower treatment capacities (Cheng and $\mathrm{Hu}, 2010$ ).

To estimate the hazardous air pollutant emission inventory from MSW incineration in China, Tian et al. (2012d) have compiled and summarized the comprehensive average emission factors of hazardous $\mathrm{HMs}(\mathrm{Hg}, \mathrm{As}, \mathrm{Pb}, \mathrm{Cd}, \mathrm{Cr}, \mathrm{Ni}$, and $\mathrm{Sb})$ for MSW incineration from published literature. Additionally, the emission ceiling of HMs for the existing incinerators in the newly issued standard (GB 18485-2014) which will be conducted in 2016 is approximately comparable to that in Directive 2000/76/EC (see Supplement, Table S18). Here, we presume the best emission factors of HMs in China for MSW in 2016 are almost equivalent to those in developed EU countries in 2000. Based on specific emission fac- 
tors of HMs for MSW incineration from published literature (Nriagu, 1979; Pacyna, 1984; Nriagu and Pacyna, 1988) and certain emission factors of HMs with uncontrolled technology from AP42, Fifth Edition, Volume I, Chapter 2: Solid Waste Disposal (US EPA, 1996), the unabated emission factors of HMs from this source category are determined. Specific emission factors of various HMs from MSW incineration can be seen in the Supplement, Table S16.

\subsubsection{HM emission factors of brake and tyre wear}

Brake linings as well as tyre wear of vehicles are known as one of the important emission sources of particulate matter to the surrounding environment, particularly in urban areas (Hjortenkrans et al., 2007). Notably, not all of the worn materials of brake lining and tyre will be emitted into the atmosphere as airborne particulate matter (Hulskotte et al., 2006). Here, we adopt the average emission factors of TSP from brake wear and tyre wear for passenger cars $\left(0.0075\right.$ and $\left.0.0107 \mathrm{~g} \mathrm{~km}^{-1}\right)$, light-duty trucks $(0.0117$ and $\left.0.0169 \mathrm{~g} \mathrm{~km}^{-1}\right)$, and heavy-duty vehicles $(0.0365$ and $0.0412 \mathrm{~g} \mathrm{~km}^{-1}$ ) obtaining from the EEA Guidebook (EEA, 2013) as the average emission factors of airborne particulate matter from brake and tyre wear.

In addition to steel as brake pad support material, the agents present in brake linings usually consist of $\mathrm{Sb}, \mathrm{Cu}$, $\mathrm{Zn}, \mathrm{Ba}, \mathrm{Sn}$, and Mo (Bukowiecki et al., 2009). Further, antimony is present in brake linings as $\mathrm{Sb}_{2} \mathrm{~S}_{3}$ that serves as a lubricant and filler to improve friction stability and to reduce vibrations. $\mathrm{Sb}_{2} \mathrm{~S}_{3}$ is oxidized to $\mathrm{Sb}_{2} \mathrm{O}_{3}$ (possibly a carcinogenic substance) during the braking process, which has been proved to be partially soluble in physiological fluids (Gao et al., 2014; von Uexküll et al., 2005). Because of their excellent characteristics of thermal conductivity, copper or brass are widely used for automotive braking as a major component of friction materials (Österle et al., 2010). Additionally, although zinc is a less specific marker for brake wear than antimony and copper, it has also been reported to be another important constituent of brake wear (Johansson et al., 2009). Hence, the HMs (especially $\mathrm{Sb}$ and $\mathrm{Cu}$ ) associated with particulate matter are mainly emitted from brake wear due to relatively higher average contents of HMs in brake lining, compared to those from tyre wear (EEA, 2013).

Because of limited information and lack of field experimental tests on HM contents in brake linings and tyres in Chinese vehicles, and the substantial quantity of vehicles sold in China that are imported from foreign countries or manufactured by foreign-invested transnational vehicle companies, we presume the composition of worn materials from brake and tyre wear in terms of HMs are consistent with foreign countries (see Supplement Table S13).

\subsection{Activity data}

Coal and liquid fuels consumption data by sectors at the provincial level (e.g., power plant, coal-fired industrial boiler, coal-fired residential sector, other coal-fired sectors) are collected from China Energy Statistical Yearbooks. Industrial production data by provinces (e.g., the output of ferrous/nonferrous metal products, production of cement/glass/brick, amount of municipal waste incineration, number of vehicles) are compiled from relevant statistical yearbooks, such as China Statistical Yearbooks, the Yearbook of Nonferrous Metals Industry of China, China Steel Yearbook etc. The detailed data sources for the main sectors are listed in the Supplement, Table S19. Furthermore, trends of activity levels by different sectors in China between 2000 and 2012 are summarized in the Supplement, Figs. S1-S5.

\subsection{Evaluation of potential uncertainties}

It is necessary to examine the potential uncertainty in emissions by sources and regions to quantify the reliability, and identify the direction and degree of improvement, of emission inventories in the future. A detailed uncertainty analysis is conducted by combining uncertainties of both activity levels and emission factors, through adopting a Monte Carlo simulation (Zhao et al., 2011; Tian et al., 2014a, b). Streets et al. (2003) indicate that there is no way to judge the accuracy of activity data estimates. Furthermore, uncertainties are still inevitable when representative values are selected for specific emission sources, countries, and regions in spite of emission factors adopted from detailed experiments.

Most of the input parameters of specific activity levels and emission factors, with corresponding statistical distributions, are specified on the basis of the data fitting, or referred to the related published references (Wu et al., 2010; Zhao et al., 2011; Tian et al., 2012a, b). Additionally, for parameters with limited observation data, the probability distributions such as normal distribution and triangular distribution are assumed by the authors for corresponding sources. Further details about the probability distribution for each source discussed in this study are listed in Table S20. Finally, all of the input parameters are placed in a Monte Carlo framework, and simulations are run 10000 times to estimate the uncertainty ranges of varied $\mathrm{HM}$ emissions with a $95 \%$ confidence interval.

\section{Results and discussion}

\subsection{Temporal trend of HM emissions by source categories}

The historical trend of atmospheric emissions of $\mathrm{Hg}$, As, $\mathrm{Se}, \mathrm{Pb}, \mathrm{Cd}, \mathrm{Cr}, \mathrm{Ni}, \mathrm{Sb}, \mathrm{Mn}, \mathrm{Co}, \mathrm{Cu}$, and $\mathrm{Zn}$ by different source categories from 1949 to 2012 are illustrated in Fig. 2. The total emissions of HMs from primary anthro- 
Table 2. HM emissions from primary anthropogenic sources in China, 1949-2012 (t year ${ }^{-1}$ ).

\begin{tabular}{|c|c|c|c|c|c|c|c|c|c|c|c|c|}
\hline Year & $\mathrm{Hg}$ & As & $\mathrm{Se}$ & $\mathrm{Pb}$ & $\mathrm{Cd}$ & $\mathrm{Cr}$ & $\mathrm{Ni}$ & $\mathrm{Sb}$ & $\mathrm{Mn}$ & Co & $\mathrm{Cu}$ & $\mathrm{Zn}$ \\
\hline 1949 & 12.7 & 45.2 & 53.7 & 312.6 & 15.5 & 158.6 & 147.3 & 16.3 & 212.1 & 11.5 & 74.0 & 226.8 \\
\hline 1978 & 144.1 & 593.6 & 607.6 & 7206.2 & 82.5 & 1021.2 & 891.9 & 151.1 & 3616.5 & 295.3 & 1356.8 & 3396.0 \\
\hline 1980 & 163.1 & 791.3 & 825.8 & 9744.8 & 98.0 & 1481.4 & 1101.5 & 193.9 & 4637.4 & 387.2 & 1745.6 & 4128.4 \\
\hline 1985 & 209.7 & 1055.5 & 1168.7 & 12922.5 & 123.7 & 2353.5 & 1250.0 & 250.6 & 5736.8 & 478.8 & 2194.9 & 4896.5 \\
\hline 1990 & 261.3 & 1311.7 & 1546.4 & 17644.0 & 156.2 & 3374.7 & 1667.5 & 337.3 & 7607.8 & 624.0 & 2880.5 & 6541.9 \\
\hline 1995 & 351.1 & 1699.7 & 2179.8 & 17620.3 & 223.3 & 5155.0 & 2354.2 & 499.4 & 9454.9 & 778.7 & 4131.5 & 9564.5 \\
\hline 2000 & 316.1 & 1673.2 & 2113.0 & 20193.5 & 255.9 & 4928.7 & 2407.0 & 566.1 & 10034.7 & 842.7 & 4733.0 & 10788.6 \\
\hline 2005 & 492.3 & 2454.4 & 3058.1 & 10887.1 & 378.9 & 6828.5 & 3246.4 & 797.9 & 12195.4 & 1075.8 & 7101.1 & 15987.9 \\
\hline 2006 & 509.3 & 2501.2 & 3146.8 & 11250.2 & 398.5 & 7179.0 & 3356.7 & 826.2 & 12181.6 & 1042.8 & 7201.1 & 16895.0 \\
\hline 2007 & 533.8 & 2407.2 & 3067.2 & 11729.0 & 420.8 & 7445.2 & 3369.6 & 822.8 & 12528.9 & 1064.5 & 7600.0 & 18147.6 \\
\hline 2008 & 564.8 & 2489.7 & 3136.1 & 12213.6 & 442.4 & 7755.7 & 3248.3 & 962.9 & 12499.8 & 1056.5 & 8208.7 & 18337.4 \\
\hline 2009 & 589.7 & 2325.8 & 2936.1 & 12519.9 & 453.7 & 7810.2 & 3250.8 & 1006.0 & 12195.4 & 1010.7 & 8428.6 & 19035.8 \\
\hline 2010 & 672.0 & 2322.9 & 2880.5 & 13194.5 & 455.8 & 7465.2 & 3138.6 & 1068.1 & 12015.9 & 919.2 & 8318.8 & 20503.7 \\
\hline 2011 & 688.4 & 2422.8 & 3062.4 & 14032.4 & 493.9 & 7733.0 & 3440.1 & 1172.8 & 12657.3 & 981.2 & 9115.5 & 21876.0 \\
\hline 2012 & 695.1 & 2529.0 & 3061.7 & 14397.6 & 526.9 & 7834.1 & 3395.5 & 1251.7 & 13006.6 & 1004.6 & 9547.6 & 22319.6 \\
\hline
\end{tabular}

pogenic sources since 1949 have shown substantial shifts among varied source categories that reflect technological and economic trends and transition during this period of over 60 years. Within the year after the establishment of the People's Republic of China in 1949, the total emissions of $\mathrm{Hg}$, $\mathrm{As}, \mathrm{Se}, \mathrm{Pb}, \mathrm{Cd}, \mathrm{Cr}, \mathrm{Ni}, \mathrm{Sb}, \mathrm{Mn}, \mathrm{Co}, \mathrm{Cu}$, and $\mathrm{Zn}$ from anthropogenic sources are estimated at about 11.5-312.6t (see Table 2). The discharges of HMs on a national scale increased by 3-20 times from 1949 to 1960 due to the increasing demands for energy consumption and industrial production (especially for the period of the Great Leap Forward from 1958 to 1960 , resulting in a remarkable increasing output of industrial products), then, a substantial decrease in 1961 and 1962 of $27.6-55.7 \%$ compared to 1960 on account of the serious imbalance of economic structure and the Great Leap Forward famine caused by policy mistakes together with natural disasters (Kung and Lin, 2003). In spite of the negative growth of heavy metal emissions in individual years such as 1967, 1974, and 1976, the annually averaged growth rates of national emissions of HMs from primary anthropogenic sources were still as high as $0.2-8.4 \%$ during the period of 1963 to 1977.

Subsequently, the policy of openness and reformation was issued by the Chinese central government. With the implementation of this policy from 1978 to 2012, China's GDP has been growing at an average annual growth rate of about $9.8 \%$, resulting in tremendous energy consumption and enormous output of industrial products. As can be seen from Fig. 2, historically there have been two periods during which the total emissions of HMs (except $\mathrm{Pb}$ ) increased rapidly after 1978. The first one is the period of 1978 to 2000, except for one remarkable fluctuation from 1998 to 1999, which reflects a decrease in input of raw materials and output of industrial products mainly owing to the influence of the Asian financial crisis (Hao et al., 2002). The second one is the pe- riod of the 10th Five-Year Plan (10th FYP, from 2001 to 2005) in which a sharp increase in emissions of $\mathrm{Hg}$, As, $\mathrm{Se}, \mathrm{Cd}, \mathrm{Cr}, \mathrm{Ni}, \mathrm{Sb}, \mathrm{Mn}, \mathrm{Co}, \mathrm{Cu}$, and $\mathrm{Zn}$ occurred, with the emissions increasing from about 268.0-11308.6 $\mathrm{t}$ in 2001 to about 378.9-15987.9t in 2005, at an annual average growth rate of $4.8-12.0 \%$ (see Table 2).

In terms of the lead content requirement in gasoline, the past 64 years since the foundation of the PR China (1949 to 2012) can be divided into two phases: the leaded gasoline period (1949 to 1990: gasoline with high lead content $\left(0.64 \mathrm{~g} \mathrm{~L}^{-1}\right)$; 1991-2000: gasoline with low lead content $\left.\left(0.35 \mathrm{~g} \mathrm{~L}^{-1}\right)\right)$, and the unleaded gasoline period (2001 to $2012,0.005 \mathrm{~g} \mathrm{~L}^{-1}$ ). As a result, the discharge of $\mathrm{Pb}$ from primary anthropogenic sources experienced two fluctuations over the 64 year period. The first sharp emission decline occurred in 1991, and the total emissions decreased by $26.2 \%$ from $17644.0 \mathrm{t}$ in 1990 to $13029.6 \mathrm{t}$ in 1991 , mainly because the average $\mathrm{Pb}$ content in leaded gasoline regulated by GB 484-89 decreased about $45.3 \%$ compared to that in GB 484-64. The other sharp decline occurred in 2001, and the total $\mathrm{Pb}$ emissions from primary anthropogenic sources reduced abruptly by about $61.6 \%$ in 2001 . Subsequently, along with the rapid increase of vehicle volume and oil consumption, a substantial increase was once again experienced from $7747.2 \mathrm{t}$ in 2001 to $14397.6 \mathrm{t}$ in 2012 , at an annual average growth rate of about $5.8 \%$.

Due to technological progress resulting in relatively low emission factors of HMs, and economic development bringing about high coal consumption and industrial products output, the trends of total atmospheric emissions for different HMs in China are diverse during the period of 2006 to 2012 (Cheng et al., 2015). Generally speaking, the national atmospheric emissions of $\mathrm{Hg}, \mathrm{Pb}, \mathrm{Cd}, \mathrm{Cr}, \mathrm{Sb}, \mathrm{Cu}$, and $\mathrm{Zn}$ increased at an annual average growth rate of $1.5-7.2 \%$ from 2006 to 2012. In spite of the remarkable growth in coal con- 

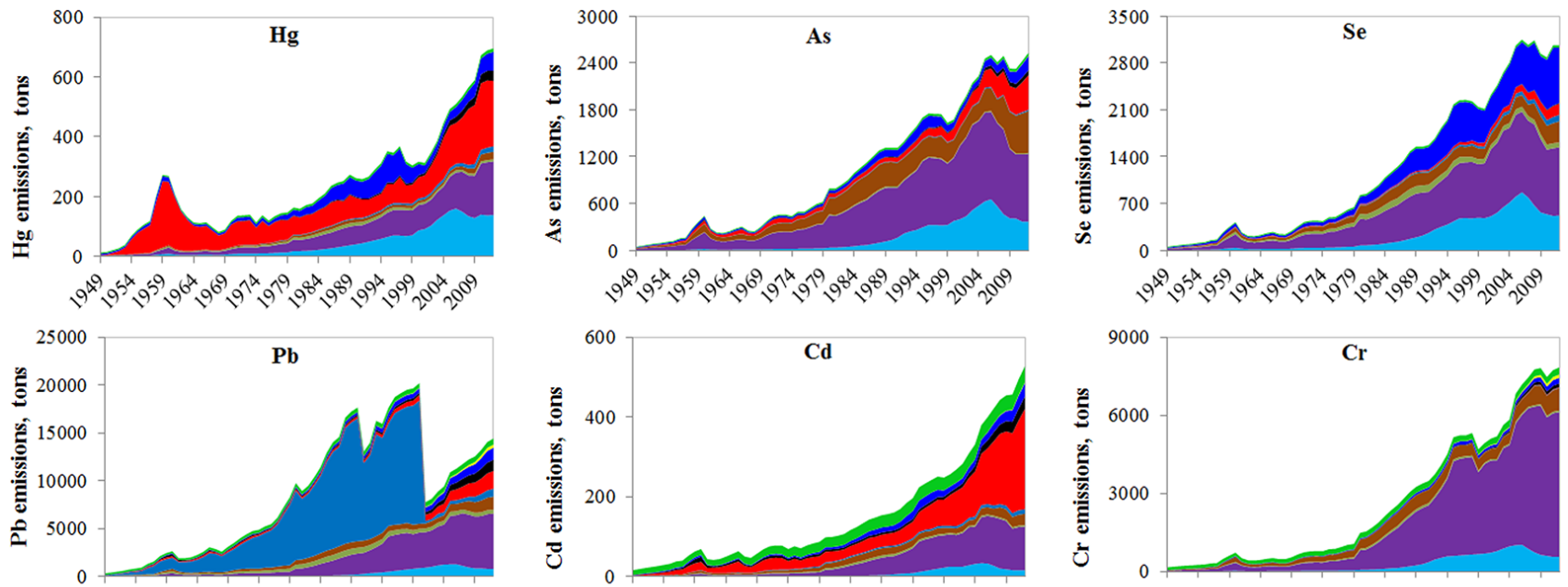

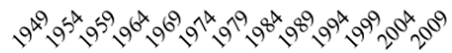

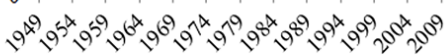

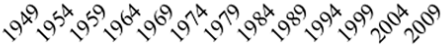
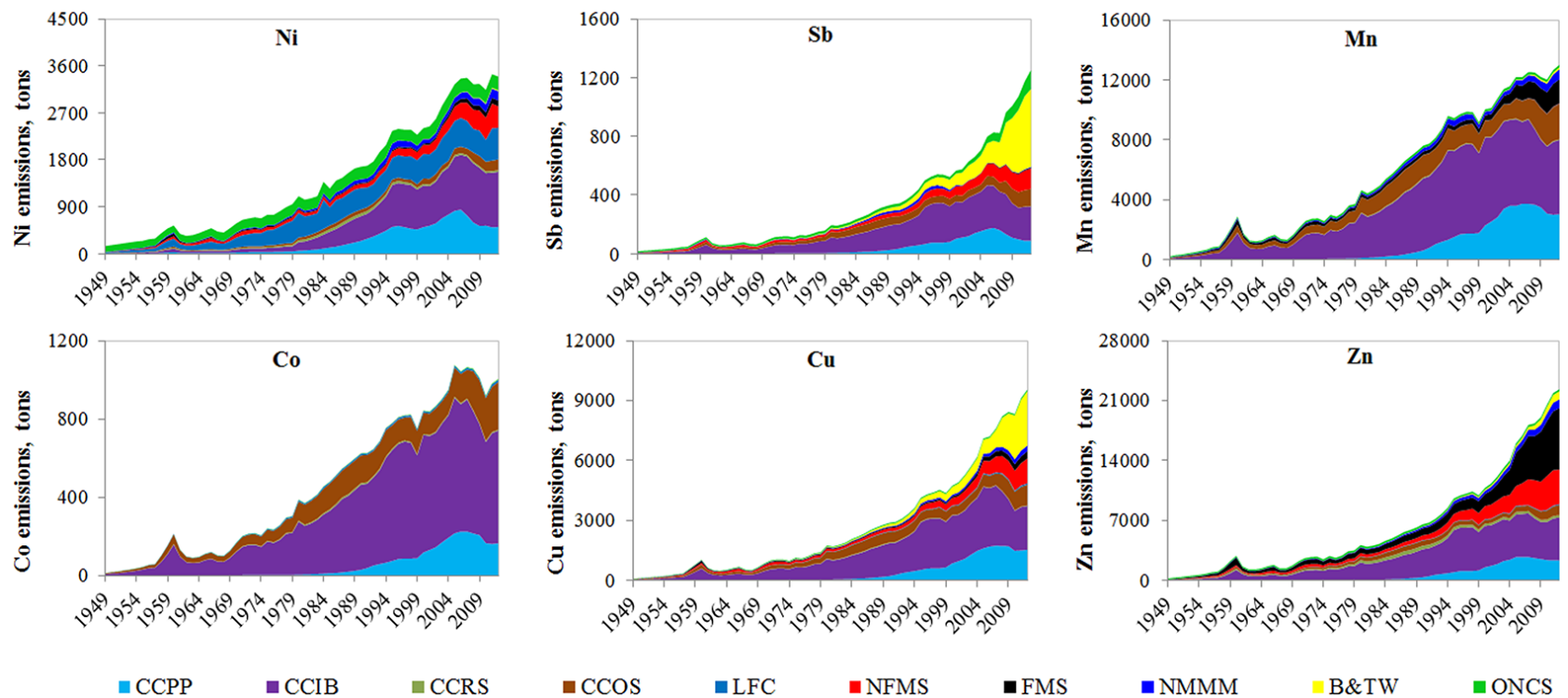

Figure 2. Historical trends of atmospheric $\mathrm{HMs}(\mathrm{Hg}, \mathrm{As}, \mathrm{Se}, \mathrm{Pb}, \mathrm{Cd}, \mathrm{Cr}, \mathrm{Ni}, \mathrm{Sb}, \mathrm{Mn}, \mathrm{Co}, \mathrm{Cu}$, and $\mathrm{Zn}$ ) emissions from primary anthropogenic sources in China, 1949-2012. CCPP, coal consumption by power plants; CCIB, coal consumption by industrial boilers; CCRS, coal consumption by residential sectors; CCOS, coal consumption by other sectors; LFC, liquid fuels combustion; NFMS, nonferrous metal smelting; FMS, ferrous metal smelting; NMMM, non-metallic minerals manufacturing; B\&TW, brake and tyre wear; ONCS, other non-coal sources (including BB, biomass burning; and MSWI, municipal solid waste incineration).

sumption and gross industrial production, the national As, $\mathrm{Se}, \mathrm{Ni}, \mathrm{Mn}$, and Co emissions are well restrained in this period. These are mainly due to the different volatility of these 12 elements during the high temperature process resulting in diverse release rates of furnaces and synergistic removal efficiencies of control measures (Xu et al., 2004).

Due to limited information about historical ground-level concentrations of $12 \mathrm{HMs}$ in different cities in China, the temporal characteristics of atmospheric concentrations of four $\mathrm{HMs}(\mathrm{As}, \mathrm{Pb}, \mathrm{Cr}$, and $\mathrm{Cu}$ ) in Beijing during 2000 to 2012 are used as valid index to verify whether or not the trend of historical HM emissions is reasonable (see Supple- ment Fig. S6). The data sources and specific values about atmospheric concentrations of $\mathrm{As}, \mathrm{Pb}, \mathrm{Cr}$, and $\mathrm{Cu}$ in Beijing during 2000 to 2012 are listed in the Supplement, Table S21. It should be acknowledged that the verification method applied in this study has certain limitations on account of sampling discrepancies, including sampling time, sampling site, and detection method etc. Therefore, the historical variation trends of HM emissions may be inconsistent with those of ambient concentrations of HMs in some years.

As can be seen from Fig. S6, minimum values of the atmospheric concentrations of $\mathrm{As}, \mathrm{Pb}, \mathrm{Cr}$, and $\mathrm{Cu}$ occur in 2008. This is mainly because most of the aerosol samples 


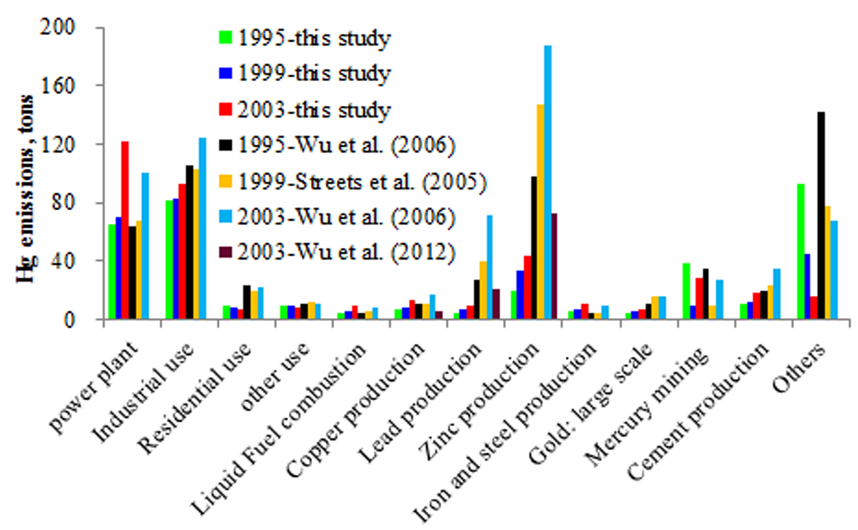

Figure 3. Estimate of annual $\mathrm{Hg}$ emissions from primary anthro-

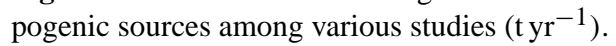

compiled from published papers are collected during August in that year, the time during which China hosted the Beijing Olympics under which a series of strict measures about energy-saving and pollution reduction were implemented, such as suspending production of high polluting industries in the Beijing and neighboring municipalities, restricting the driving of vehicles on alternate days under an even-odd license plate system, limiting pollutant emissions from coal combustion facilities in Beijing and the surrounding provinces etc. Consequently, the variation trends of atmospheric concentrations of $\mathrm{As}, \mathrm{Pb}, \mathrm{Cr}$, and $\mathrm{Cu}$ have some discrepancies with those of historical emissions of the above four HMs in Beijing in 2008. However, the historical emission trends of $\mathrm{As}, \mathrm{Pb}, \mathrm{Cr}$, and $\mathrm{Cu}$ are consistent with those of atmospheric concentrations of the above four HMs during 2000 to 2012 in general (see Fig. S6), which indicates that the historical trend of $\mathrm{HM}$ emissions estimated by this study is reasonable.

Until now, the comprehensive and special studies on various $\mathrm{HM}$ (except $\mathrm{Hg}$ ) emissions in China are quite limited. Therefore, only a detailed comparison with $\mathrm{Hg}$ emission estimates from other studies is discussed in this study (see Fig. 3). Specifically, limited data on China's Hg emissions can be cited directly from the global $\mathrm{Hg}$ inventories estimated by Pacyna and Pacyna (2001), Pacyna et al. $(2006,2010)$ and Streets et al. (2011). Consequently, here, we mainly focus on comparing our estimations with the results from China's specialized $\mathrm{Hg}$ emission inventories estimated by Streets et al. (2005) and Wu et al. (2006).

Overall, the estimated $\mathrm{Hg}$ emissions from fuel combustion (except for the subcategory of coal consumption by residential sectors) in this work are substantially consistent with those reported by Streets et al. (2005) and Wu et al. (2006), although the values calculated for the same year are somewhat different. This may be mainly attributed to the difference in the averaged provincial content of $\mathrm{Hg}$ in raw coal. In our study, according to a comprehensive investigation of published literature, we determine the national averaged $\mathrm{Hg}$ content in China to be $0.18 \mathrm{mg} \mathrm{kg}^{-1}$ by using a bootstrap simulation method, a little lower than that used by the above two studies $\left(0.19 \mathrm{~m} \mathrm{~kg}^{-1}\right)$. Another important factor influencing the result is the difference of removal effectiveness of Hg through traditional APCDs. Nevertheless, the estimated $\mathrm{Hg}$ emissions from coal consumption by residential sectors by Streets et al. (2005) and Wu et al. (2006) are higher than our estimation in the same year. This is mainly because the emission factor of $\mathrm{Hg}$ from coal consumption by residential sectors is cited from Australia NPI in this paper, which is only approximately half of that which EPA adopted in the above two studies. In terms of $\mathrm{Hg}$ emissions from industrial processes, the estimated $\mathrm{Hg}$ emissions in this study are generally lower than those in other $\mathrm{Hg}$ emission inventories in the same year. This may be because we have adopted S-shaped curves to quantify the positive effects on emission reduction of pollutants by technology improvement, so that the emission factors adopted in this study are generally lower than those used in studies of Streets et al. (2005), Wu et al. (2006), and Wu et al. (2012) in the same year. In addition, some anthropogenic sources with high uncertainties are not taken into account in this work due to the lack of detailed activity data for the long period. Certain natural sources (e.g., forest burning, grassland burning) are also not included in this study. Consequently, our estimated total $\mathrm{Hg}$ emissions are lower than those in inventories estimated by Streets et al. (2005) and Wu et al. (2006).

\subsubsection{HM emissions from coal combustion by power plants}

The power plant sector represents the largest consumer of coal in China. The thermal power generation increased from 3.6 TWh in 1949 to $3925.5 \mathrm{TWh}$ in 2012 (NBS, 2013a). Meanwhile, coal burned by power plants has increased from 5.2 to $1785.3 \mathrm{Mt}$ (NBS, 2013b), with an annual growth rate of $9.9 \%$ and a percentage share of the total coal consumption increasing from 22.7 to $50.6 \%$. For the period of 1949 to 2005, the emissions of HMs from coal combustion by power plants increased in rough proportion to coal consumption. However, this trend began to change after 2006 due to the implementation of policies of energy-saving and pollution reduction, especially the strengthening of $\mathrm{SO}_{2}$ emission control for coal-fired power plants (Zhu et al., 2015).

Presently, the combination of pulverized-coal boilers plus ESPs plus WFGD is the most common APCDs configuration in coal-fired power plants of China. By the end of 2012, the installed capacities of FGD in power plants increased by nearly 14 times compared with those in 2005 , reaching about $706.4 \mathrm{GWe}$, accounting for approximately $86.2 \%$ of the installed capacity of total thermal power plants (MEP, 2014a). Of all of the units with FGD installation, approximately $89.7 \%$ adopt the limestone-gypsum WFGD process. The discharges of $\mathrm{Hg}, \mathrm{As}, \mathrm{Se}, \mathrm{Pb}, \mathrm{Cd}, \mathrm{Cr}, \mathrm{Ni}, \mathrm{Sb}, \mathrm{Mn}, \mathrm{Co}$, 
$\mathrm{Cu}$, and $\mathrm{Zn}$ from coal combustion by power plants in 2012 are estimated at about 15.2-3038.9 $\mathrm{t}$ (see Fig. 2), which have decreased by $1.7-11.8 \%$ annually since 2006 . Moreover, the distinction of integrated co-benefit removal efficiencies of these elements for the typical APCD configurations is the primary reason for the obvious variations of the declining rates among varied HMs, as illustrated in Table 1 and Fig. 2.

\subsubsection{HM emissions from coal consumption by industrial boilers}

In general, coal combusted by industrial boilers is used to provide hot water and heating for industrial production processes. With the development of China's economy (GDP increased from CNY (Chinese Yuan) 46.6 billion in 1949 to CNY 51894.2 billion in 2012), coal consumption by industrial boilers increased at a relatively lower growth rate than the power sector, from 11.5 Mt in 1949 to $1205.6 \mathrm{Mt}$ in 2012 (NBS, 2013b). According to the statistical data from China Machinery Industry Yearbook, the combination of stokerfired boiler plus wet scrubber and cyclone is the most common configuration in coal-fired industrial sectors of China, especially for the small- and medium-scale boilers (CMIF, 2013).

As can be seen from Fig. 2, the emission trends of HMs from coal consumption by industrial boilers are consistent with the total national emissions trends between 1949 and 1997, and negative growth appears in 1998 and 1999 due to the decreased coal consumption resultant of the Asian financial crisis (Hao et al., 2002; Tian et al., 2007, 2012b). Subsequently, the emissions of different toxic HMs from coal consumption by industrial boilers have distinct variation tendencies, mainly due to the different removal efficiencies of HMs through typical APCDs. Generally, $\mathrm{Hg}$ and $\mathrm{Pb}$ emissions from coal consumption by industrial boilers increased almost monotonically from 85.1 and $3717.8 \mathrm{t}$ in 2000 to 179.0 and $5770.0 \mathrm{t}$ in 2012, with an annual growth rate of about 6.4 and $3.7 \%$, respectively. However, the discharges of $\mathrm{Mn}$ from coal consumption by industrial boilers decreased about 1.2 times from 5866.0 to $4951.8 \mathrm{t}$ during this period (20002012). Moreover, the discharges of the other nine HMs (As, $\mathrm{Se}, \mathrm{Cd}, \mathrm{Cr}, \mathrm{Ni}, \mathrm{Sb}, \mathrm{Co}, \mathrm{Cu}$ and $\mathrm{Zn}$ ) from coal consumption by industrial boilers present a trend of first an increase, and then a decrease overall, with the implementation of policies of saving energy and pollution reduction in the coal-fired industrial boilers sector, especially the growing application of high-efficiency dust collectors and various types of combined dust and $\mathrm{SO}_{2}$ removal devices.

\subsubsection{HM emissions from metal smelting and other primary sources}

Historically, a sharp fluctuation of $\mathrm{Hg}$ discharges from the nonferrous metal smelting sector occurred in the period of the Great Leap Forward to the Great Leap Forward famine (an increase from $92.6 \mathrm{t}$ in 1957 to $221.7 \mathrm{t}$ in 1959 , then a decrease rapidly to $104.0 \mathrm{t}$ in 1963); this is mainly due to the rapid increase or decline of mercury mining outputs in this period (an increase from 1060 $\mathrm{t}$ in 1957 to $2684 \mathrm{t}$ in 1959, then a decrease rapidly to $1345 \mathrm{t}$ in 1963). Subsequently, a sharp increase of emissions of $\mathrm{Hg}$ occurred, with emissions from about 60.6 $\mathrm{t}$ in 1998 increasing to about $218.6 \mathrm{t}$ in 2012, at an annually averaged growth rate of $9.6 \%$. Simultaneously, the primary contributor of $\mathrm{Hg}$ emissions from the nonferrous metal smelting sector has changed to the subsector of primary Zn smelting, which made up about 36.9-52.7\% of the sector during 1998 to 2012. Unlike Hg emissions, the emissions of $\mathrm{As}, \mathrm{Se}, \mathrm{Pb}, \mathrm{Cd}, \mathrm{Ni}, \mathrm{Sb}, \mathrm{Cu}$, and $\mathrm{Zn}$ from the nonferrous metal smelting sector increased by approximately $7-15$ times to $442.3,1856.4,251.8,412.7,140.6,1240.9$, and $4025.6 \mathrm{t}$ in 2012 , respectively. This is mainly because the reduced shares of HM emissions from the nonferrous metal smelting sector, caused by increasing advanced pollutants control devices installation, were partly counteracted by the rapid growth of nonferrous metals production.

A steady increase of $\mathrm{HM}$ emissions from the pig iron and steel industry accompanied by certain undulations occurred from 1949 to 1999 (see Fig. 2). Specifically, because of the emphasis on the backyard furnaces for steel production in the period of the Great Leap Forward Movement, a sharp fluctuation of emissions occurred during the period of 1958 to 1963, with the emissions of $\mathrm{Hg}$, As, $\mathrm{Se}, \mathrm{Pb}, \mathrm{Cd}, \mathrm{Cr}, \mathrm{Ni}, \mathrm{Sb}, \mathrm{Mn}$, $\mathrm{Cu}$, and $\mathrm{Zn}$ almost doubling (NBS, 2013b). Although emission factors gradually reduced between 2000 and 2012, the output of pig iron and steel has rapidly increased from 131.0 and $128.5 \mathrm{Mt}$ in 2000 to 663.5 and $723.9 \mathrm{Mt}$ in 2012 and, as a result, the emissions of $\mathrm{Hg}, \mathrm{As}, \mathrm{Se}, \mathrm{Pb}, \mathrm{Cd}, \mathrm{Cr}, \mathrm{Ni}, \mathrm{Sb}, \mathrm{Mn}$, $\mathrm{Cu}$, and $\mathrm{Zn}$ from this sector have quadrupled or quintupled in the past 12 years. Especially, the share of $\mathrm{Zn}$ emissions from the ferrous metal smelting sector to the national emissions has increased from 13.1 to $32.2 \%$. Therein, the steel production industry represents the dominant contributor to Zn emissions, accounting for about $60.9-62.9 \%$ during this period.

In order to facilitate understanding of historical HM emissions in China, details about temporal variation trends of HM emissions from liquid fuel combustion and brake and tyre wear are discussed in the Supplement Sect. S3.

\subsection{Composition of $\mathrm{HM}$ emissions by province and source category in $\mathbf{2 0 1 0}$}

The total emissions of $\mathrm{Hg}, \mathrm{As}, \mathrm{Se}, \mathrm{Pb}, \mathrm{Cd}, \mathrm{Cr}, \mathrm{Ni}, \mathrm{Sb}, \mathrm{Mn}$, $\mathrm{Co}, \mathrm{Cu}$, and $\mathrm{Zn}$ from primary anthropogenic sources by provinces in China for the year 2010 are estimated at about 72955.1 t. As can be seen in Fig. 4, coal combustion sources represent the major contributors of $\mathrm{Hg}, \mathrm{As}, \mathrm{Se}, \mathrm{Pb}, \mathrm{Cr}, \mathrm{Ni}$, $\mathrm{Mn}, \mathrm{Co}$, and $\mathrm{Cu}$ emissions and are responsible for about 50.6, $74.2,64.6,60.1,90.4,56.2,80.9,98.6$, and $53.4 \%$ of total emissions, respectively, while their contribution to the total 

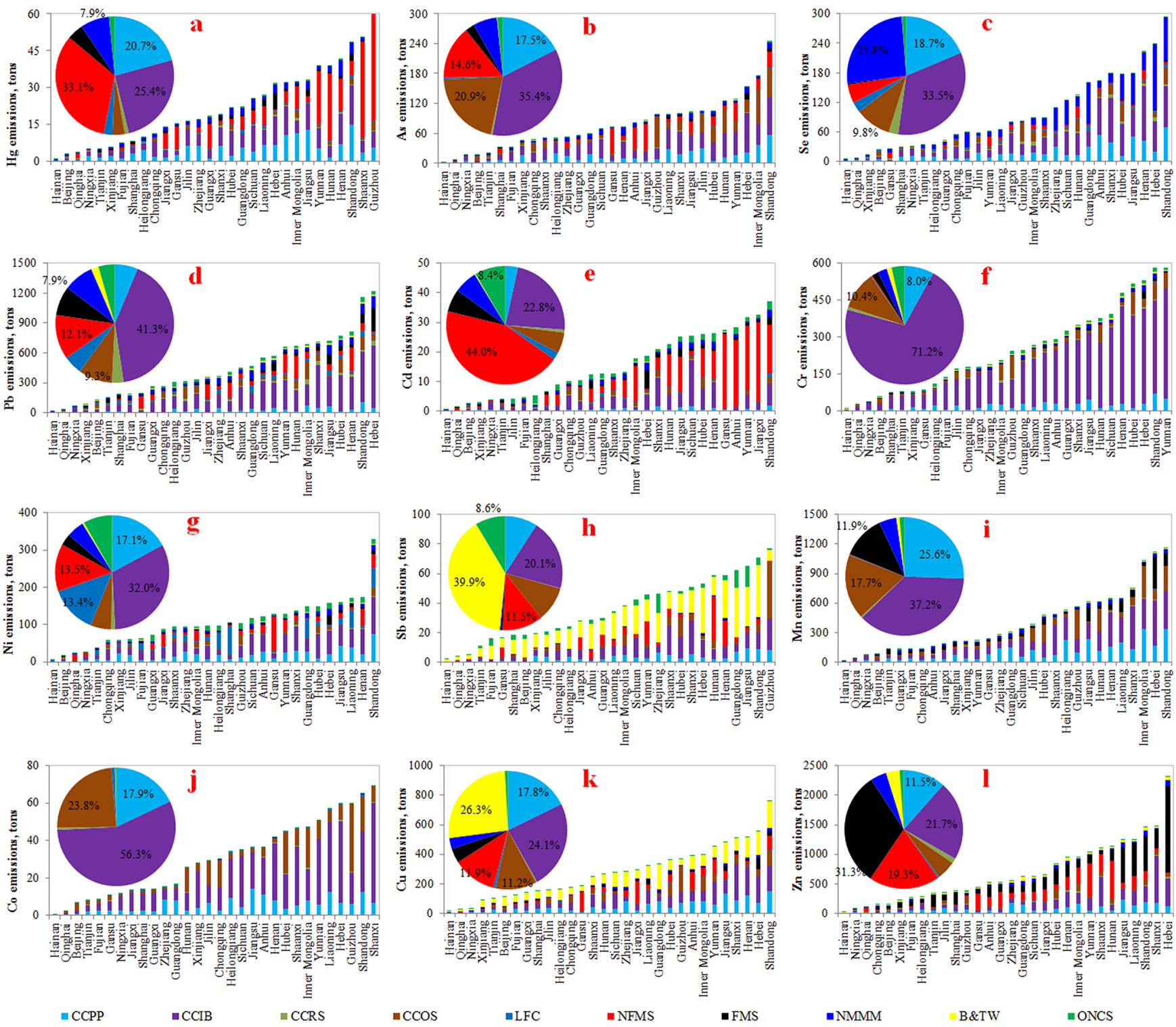

Figure 4. Provincial HM emissions from anthropogenic sources and national composition by source categories in 2010.

$\mathrm{Cd}, \mathrm{Sb}$, and $\mathrm{Zn}$ emissions are relatively lower, at about 32.7, 39.3 , and $39.8 \%$, respectively.

Among all the coal-consuming sub-sectors, coal consumption by industrial boilers ranks as the primary source of total national emissions of $12 \mathrm{HMs}$, with the average proportion about $57.7 \%$ of the total emissions from coal combustion. This may be attributed to the significant coal consumption of industrial boilers (about 1117.3 Mt in 2010) and the relatively high share of boilers with inadequate APCDs (Cheng et al., 2015; NBS, 2013b).

As the largest coal consumer in China, coal consumption by power plants is identified as the second largest contributor and accounts for about $14.0 \%$ in total national emissions of $12 \mathrm{HMs}$. In order to achieve the emission reduction of PM,
$\mathrm{SO}_{2}$, and $\mathrm{NO}_{x}$ for satisfying the national or local emission reduction goals for the year 2010 (the end year of 11th FYP) (NBS, 2011; Tian et al., 2014a), control policies have been implemented, including replacement of small coal-fired plant units with large and high-efficiency units and the continuously increasing installation rate of advanced APCDs systems (e.g., ESP, FFs, WFGD, SCR). Consequently, the final discharge rates of HM from power plants have decreased obviously, even though the volume of coal consumption has grown substantially (see Fig. 2 and Fig. S1).

China has been the world's largest producer of pig iron and steel by a rapidly growing margin. By the end of 2012, the output of steel has amounted to $723.9 \mathrm{Mt}$, accounting for about $46 \%$ of worldwide steel production (CISA, 2013). De- 
spite the enormous achievement by China's iron and steel industry, China is still featured as a steel producer with low energy efficiency and high pollutant emissions level, compared with other major steel-producing countries (Guo and $\mathrm{Fu}$, 2010). Because of limited application of FGD and de- $\mathrm{NO}_{x}$ devices and poor control of PM, the ferrous metal smelting sector ranks as the third largest contributor, responsible for about $13.2 \%$ of the total national emissions of $12 \mathrm{HMs}$. In terms of $\mathrm{Zn}$ emissions, the share of this sector is dominant, accounting for about $32.2 \%$ of the total.

Regarding nonferrous metal smelting emissions, the primary smelting processes resulting in HM emissions discharge far more pollution than those emitted from the secondary smelting processes. Nonferrous metal smelting, as the fourth largest contributor, accounting for about $11.0 \%$ of total emissions, represents the primary contributor to the discharges of $\mathrm{Hg}$ and $\mathrm{Cd}$. Therein, primary $\mathrm{Cu}$ smelting contributes the largest part of most of these elements, including $89.5 \%$ for As, $37.3 \%$ for $\mathrm{Pb}, 74.8 \%$ for $\mathrm{Cd}, 38.7 \%$ for $\mathrm{Ni}$ and $76.6 \%$ for $\mathrm{Cu}$; primary $\mathrm{Pb}$ smelting is the major source of $\mathrm{Sb}$ and $\mathrm{Pb}$; primary $\mathrm{Zn}$ smelting accounts for the largest proportion of $\mathrm{Hg}$ and $\mathrm{Zn}$ emissions among the nonferrous metal smelting category. In addition, with respect to $\mathrm{Hg}$ emissions from the nonferrous metal smelting sector, the mercury smelting industry is the other dominant subcategory source, with a share of about $33.0 \%$ of nonferrous metal smelting emission in 2010.

It can be concluded that the emissions of HMs from brake wear are associated with the vehicle population, vehicle mileage as well as the content of HMs in brake linings and tyres. Currently, numerous studies have reported that airborne HMs (e.g., $\mathrm{Sb}, \mathrm{Cu}, \mathrm{Zn}$ ) in urban areas are associated with road traffic and more definitely with emissions from brake wear (Gómez et al., 2005; Hjortenkrans et al., 2007). As can be seen from Fig. 4h and k, the brake and tyre wear sector is the largest source of national $\mathrm{Sb}$ and $\mathrm{Cu}$ emissions -39.9 and $26.3 \%$, respectively. Brake wear is the dominant sub-contributor, accounting for over 99.9 and $99.6 \%$ for $\mathrm{Sb}$ and $\mathrm{Cu}$ emissions from this sector in 2010 , respectively. This is mainly due to the high content of $\mathrm{Sb}$ and $\mathrm{Cu}$ in the brake linings (see Table S13, Hjortenkrans et al., 2007) and the explosive expansion of the vehicle population in China (see Fig. S5). Nevertheless, the adverse effects of airborne PM originating from brake wear on human health and the ecosystem have still not received sufficient attention from the policymakers as well as the public.

Although the non-metallic mineral manufacturing sector is not the dominant source of most HMs, the discharge of Se from this sector makes it the largest contributor to the total. Within this category, the glass production sector discharges about $92.9 \%$ of the total Se emissions due to the widespread application of selenium powder as a decolorizing agent in the glass production process and the huge output of glass production (Kavlak and Graedel, 2013).
As can be seen from Fig. 4a-1, the source contributions on the provincial scale in 2010 vary substantially due to the difference of industrial conformations and energy structures (Cheng et al., 2015; NBS, 2013a, b). Among the provinces with high HM emissions, Shandong ranks as the largest province with $\mathrm{As}, \mathrm{Se}, \mathrm{Cd}, \mathrm{Ni}, \mathrm{Mn}$, and $\mathrm{Cu}$ emissions; accounting for about $8.1-10.6 \%$ of the national emissions; Hebei contributes the largest part of about 9.3 and $11.3 \%$ to national $\mathrm{Pb}$ and $\mathrm{Zn}$ emissions respectively; Guizhou represents the primary province with $\mathrm{Hg}$ and $\mathrm{Sb}$ emissions; the key provinces with $\mathrm{Cr}$ and $\mathrm{Co}$ emissions are found in Yunnan and Shanxi, respectively. These can be mainly attributed to the follow reasons (NBS, 2013a, b; Wu et al., 2008): (1) the enormous coal consumption of industrial boilers, the considerable electric power generation, a substantial increase of vehicle population, and the huge output of industrial products in Shandong, (2) the flourishing pig iron and steel production in Hebei, (3) the dominant outputs of mercury and obviously high average concentration of $\mathrm{Sb}$ in feed coals in Guizhou (about $6.0 \mu \mathrm{gg}^{-1}$, which is approximately 4 times higher than the national averaged concentration of $\mathrm{Sb}$ in coal as consumed in China, see Table S8), (4) the booming cokemaking industry in Shanxi, and (5) the relatively high concentration of $\mathrm{Cr}$ in feed coals in Yunnan (about $71.7 \mu \mathrm{g} \mathrm{g}^{-1}$, which is 2 times higher than the national averaged concentration of $\mathrm{Cr}$ in coal as consumed in China, see Table S8).

\subsection{Spatial variation characteristics of HM emissions}

The spatial distribution patterns of HM emissions from anthropogenic sources are illustrated in Fig. 5. In this study, 1796 power plants with capacity larger than $6000 \mathrm{~kW}, 566$ copper/lead/zinc smelting plants, 33 large iron and steel plants, and $101 \mathrm{MSW}$ incineration plants are identified as large point sources and their emissions are precisely allocated at their latitude/longitude coordinates (the geographical distribution of 2496 point sources in China is shown in the Supplement, Fig. S7). It should be noted here, the emissions from point sources of nonferrous metal smelting industry and ferrous metal smelting industry contain two parts: emissions originating from fuel combustion and emissions emitted from industrial production processes. Except for the emissions from point sources discussed above, the remaining anthropogenic sources in the provincial level are all treated as regional area sources. The specific method of geographical location for area sources has been discussed in our previous studies (Tian et al., 2012b, c).

The spatial variation is closely related with the unbalanced economic development and population density in the Chinese mainland, so that these 12 typical HM emissions are distributed very unevenly from one area to another, with the annual As emissions at the province level ranging from $0.009 \mathrm{~kg} \mathrm{~km}^{-2}$ in Qinghai to $1.6 \mathrm{~kg} \mathrm{~km}^{-2}$ in Shandong, for instance. One notable characteristic of the spatial distribution of China's HM emissions is that the HM emission in- 

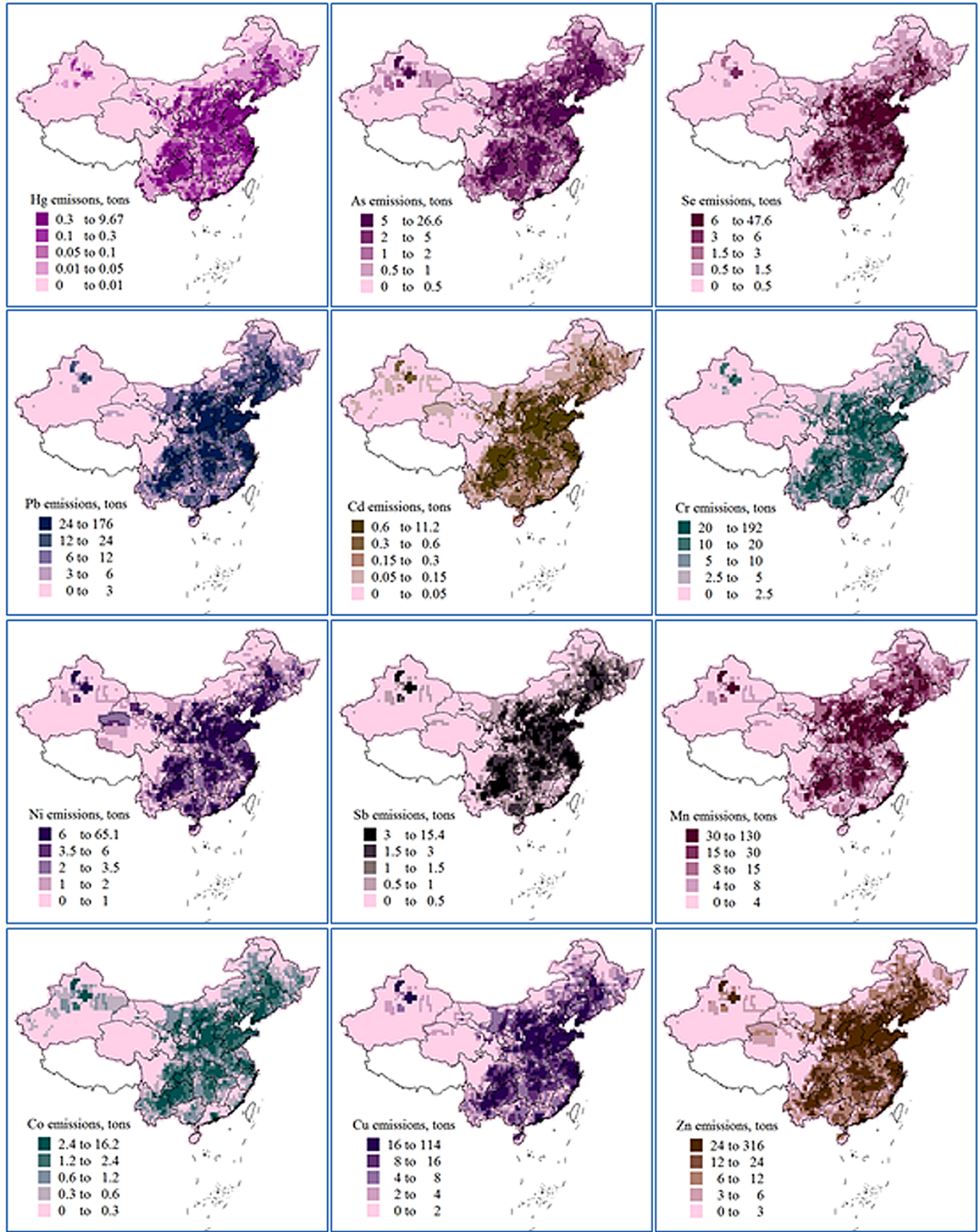

Figure 5. Gridded HM emissions from anthropogenic sources for the year $2010\left(0.5^{\circ} \times 0.5^{\circ}\right.$ resolution; units, kilograms per year per grid cell).

tensities are much higher in central and eastern China than those in western China, and the coastal regions are classed as the most polluted areas of varied HMs. The emissions of HMs from Hebei, Shandong, Henan, Jiangsu, Shanxi, and Liaoning provinces almost account for about $39.4 \%$ of the total emissions of these HMs. These six provinces above are characterized by extensive economy growth mode, a large volume of coal consumption and various industrial products output, as well as a high population density. Therefore, more energy consumption and higher travel demand characterize these six provinces, compared to other provinces and districts, resulting in higher HM emission intensity. 


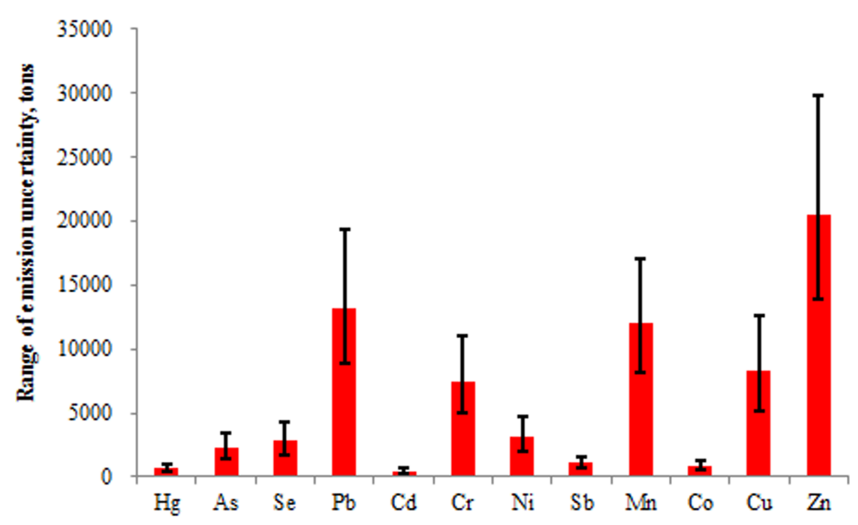

Figure 6. Uncertainties in the total emissions of HMs in China in 2010 (uncertainties in the emissions of HMs by source categories in China in 2010 can be seen in the Supplement, Table S22).

Moreover, several provinces in the southwestern and central-southern regions also play a prominent role for these 12 HM emissions, especially for Guizhou, Sichuan, Yunnan, Hubei, and Hunan provinces. In general, Guizhou province starts out with high emissions of HMs from coal consumption by other sectors, mainly owing to both the high HM contents in the feed coals and the large magnitude of coal consumption by this sector. In addition, the nonferrous industries of Hunan and Yunnan provinces are flourishing, especially the copper and zinc smelting industries. Consequently, the nonferrous metal smelting sector is seen as one of the major sources of $\mathrm{Cu}$ and $\mathrm{Zn}$ emissions in these two provinces.

The situations of atmospheric HM concentrations in the aerosols of 44 major cities in China during the last 10 years have been reviewed comprehensively by Duan and Tan (2013). Their results indicate that the ambient concentrations of $\mathrm{HMs}$ ( $\mathrm{As}, \mathrm{Pb}, \mathrm{Cd}, \mathrm{Cr}, \mathrm{Ni}, \mathrm{Mn}, \mathrm{Cu}$, and $\mathrm{Zn}$ ) are high in some cities, including Beijing, Tianjin, Shijiazhuang, Shenyang, Harbin, Jinan, Zhengzhou, Hangzhou, Nanjing, Hefei, Xian, Yinchuan, Urumqi, Wuhan, Changsha, Chongqing, Guangzhou, Shenzhen, Foshan, Shaoguan, and others. For HM emissions on the urban scale in 2010, these 20 cities with high HMs concentrations also represent the cities with the highest HM emissions in China (see Fig. 5). In general, the spatial distribution characteristics of gridded HM emissions from primary anthropogenic sources for the year 2010 in this study are reasonable and representative of the real situation of this HM pollution.

\subsection{Uncertainty analysis}

Emissions of varied HMs from primary anthropogenic sources with uncertainties in 2010 are summarized in Fig. 6 and Supplement Table S22. As can be seen, the overall uncertainties of the total emissions in our inventories quantified by the Monte Carlo simulation are -39.1 to $50.8 \%$. Among all the coal combustion sectors, uncertainties for thermal power plants emissions are smallest, whereas those for coal-fired residential sectors and other coal-fired sectors are considerable. These are mainly attributed to the relatively poor resolution of coal burning technologies and emission control devices in these two subcategories. In contrast, relatively higher uncertainties are observed in the non-coal combustion categories, particular for non-metallic mineral manufacturing and brake and tyre wear emissions. These high uncertainties of HM emissions can be mainly attributed to imprecise statistics information, poor source understanding, as well as the absence of adequate field test data in China.

The earlier statistical data for activity levels are considered to have high uncertainty for developing countries (including China) with less developed statistical systems. Unfortunately, we have to acknowledge that it is quite difficult to accurately assess the specific uncertainty of activity data from China's earlier official statistics. Akimoto et al. (2006) argue that the data of energy consumption of China during 19962003 is not recommended for use in the study of emission inventories due to the probable underestimates. However, the discrepancies in coal consumption from the power sector are considered to be less than $\pm 5 \%$, which do not dominate the emission uncertainties (Wu et al., 2010; Zhao, et al., 2008). In order to approximately quantify the uncertainty of activity data, we divide the whole period of 1949 to 2012 into three stages with respect to economic development and emission control: before reform and opening (1949-1978), intermediate stage (1979-2005), and the substantial control stage of atmospheric pollutants (2006-2012). For the activity level of anthropogenic sources obtained from official statistics after 2006, we assume normal distributions with sector-dependent uncertainties (see Supplement Table S20). On the basis of the discussion and considerations above, the uncertainty of activity data from official statistics during the two early periods of 1949-1978 and 1979-2005, is assumed to be about 2 and 1.5 times that in the period of 2006-2012.

The combined uncertainty bounds for the national emissions of $12 \mathrm{HMs}$ during the historical period are shown in Fig. S8. In general, the range of uncertainty has gradually diminished over time. For example, we calculate an uncertainty level of -90.1 to $125.7 \%$ (95\% confidence interval) in the estimate of national $\mathrm{Hg}$ emissions in 1949 , which is higher than that of the other $11 \mathrm{HM}$ emissions (between -90.0 and $119.3 \%$ ). This is mainly attributed to remarkable emissions from several $\mathrm{Hg}$ sources that have the largest uncertainty in both activity levels and emission factors, such as gold smelting and mercury mining. Since then, the relative uncertainties have gradually decreased from the beginning to the end of the period. This is primarily because more reliable activity data with a smaller coefficient of variation (CV) from related yearbooks and reports became available. The uncertainty range of national $\mathrm{Hg}$ emissions is estimated to be -40.6 to $55.8 \%$ by 2003 , which compares well with estimates of $\pm 44 \%$ for China's $\mathrm{Hg}$ emissions by Wu et al. (2006). By the end of 2012, the overall uncertainty level was reduced to 
-39.0 to $47.0 \%$ for the national HM emissions. Particularly, it should be acknowledged that emission trends of HMs are probably more uncertain than indicated. This is mainly because dynamic emission factor curves of certain sectors are set between two very distant points (e.g., 1890 and 1990 in Fig. 1), which means that the timing and rate of the decreased emission factors are really unconstrained. Nevertheless, no data are available to improve the confidence presently, which merits further investigation in the future.

Generally speaking, emission inventories are never complete and perfect, and most emissions estimates possess a significant associated uncertainty, mainly owing to the lack of representativeness of specific emission factors and the reliability of the source-specific activity data. In this study, we have made great efforts to evaluate the historical trend of these HM emissions by collecting detailed activity levels for various source categories, adopting the best available dynamic emission factors for various anthropogenic sources in China today, and integrating publication literature and reports from developed countries and districts. Nevertheless, considerable uncertainties are still present, and this may lead to under- or overestimation of HM emissions from some source categories. Consequently, more detailed investigations and long-term field tests for all kinds of coal-fired facilities and industrial production processes are in great demand.

\subsection{Proposals for future control policies}

Presently, control of atmospheric HM emissions still has not received sufficient attention by the government and public in spite of the frequent occurrence of HM pollution in China (especially for provinces with high point sources of HM emissions). The implementation of more rigorous emission standards on primary anthropogenic sources (thermal power plant, coal-fired boiler, nonferrous metallurgy, pig iron and steel production etc.) and national ambient air quality standards (NAAQS) are regarded as important triggers to promote enterprises with diminished HM emissions. Therefore, the MEP should speed up the revision of the system of hazardous air pollutant (including HM) emission standards, and strengthen the amendment of NAAQS. Especially brake wear has been confirmed to be the main source of HM emissions from traffic, particularly in urban areas. However, there is no related emission standard of air pollutants for brake wear. In the near future, the promulgation of emission standards of brake wear should be expected, which will further strengthen the control of atmospheric HM emissions in China.

In addition, some specific actions are suggested as follows: (1) lower or stop mining and burning coal with high HM concentrations in certain provinces where the coals are mainly mined from small coal mines such as Zhejiang and Guangxi (or lower or stop using high-sulfur coal in corresponding provinces due to the high affinity between HMs and pyrite in coal) (Yuan et al., 2013; Zhu et al., 2015); (2) pro- mote coal washing before combustion (the removal efficiencies of coal preparation to lower heavy metals can reach as high as approximately $30.0-60.0 \%$, see Supplement Table S9); (3) increase the application rate of advanced APCDs configurations in newly built or retrofitted coal-fired boilers; (4) initiate pilot tests or demonstration projects for specified mercury control (SMC) technologies in some sectors with high $\mathrm{Hg}$ emissions and develop comprehensive HM control technologies capable of simultaneously removing multiple heavy metals; (5) strengthen energy conservation and boost electricity and/or heat generation using cleaned energy and renewable energy, such as nuclear, wind and solar energy; (6) suspend small-scale coal-fired boilers and industrial production plants with backward emission control technologies (e.g., cement plants, ferrous smelting plants, nonferrous smelting plants); (7) eliminate outdated production technology, such as VR pyrometallurgy and ISP pyrometallurgy; and (8) improve cyclic utilization rate of nonferrous metals and ferrous metals during the period of 12th FYP etc.

\section{Conclusions}

We have calculated the historical emissions of 12 typical HMs from primary man-made activities during the period of 1949-2012, based on the detailed statistical data at a provincial level from various statistical yearbooks and adopting comprehensive time-varying dynamic emission factors from relevant research and literature. Undoubtedly, taking consideration of the economic transition and emission control technology improvement, the dynamic emission factors used in this study will enhance the accuracy and reliability of the estimation of $\mathrm{HM}$ emissions.

The total national atmospheric emissions of $\mathrm{Hg}$, As, Se, $\mathrm{Pb}, \mathrm{Cd}, \mathrm{Cr}, \mathrm{Ni}, \mathrm{Sb}, \mathrm{Mn}, \mathrm{Co}, \mathrm{Cu}$, and $\mathrm{Zn}$ from anthropogenic sources increased by about 22-128 times during the period of 1949-2012, reaching about 526.9-22319.6t in 2012.

In spite of the increasing coal consumption and gross industrial production, the national emissions of certain HMs (e.g., As, Se, Ni, Mn, Co) have been well restrained with the implementation of energy-saving and pollution reduction policies during 2006 to 2012 . Especially, the declining share of HM emissions from industrial process sources (e.g., nonferrous metal smelting, ferrous metal smelting, non-metallic mineral manufacturing) caused by increasing installation of advanced pollutants control devices, has been partially counteracted by the added industrial production yields. Additionally, both high contents of antimony and copper in brake lining and the rapid growth of civilian vehicle population are thought to be the primary reasons for continuous significant growth rate of $\mathrm{Sb}$ and $\mathrm{Cu}$ emissions from brake and tyre wear during 2000 to 2012.

The spatial distribution characteristics of HM emissions are closely related with the unbalanced regional economic development and population density in China. One notable 
characteristic is that HM emission intensities are much higher in central and eastern China than those in western China, and coastal regions are classed as the most polluted areas of HMs. Notably, because of the flourishing of the nonferrous metal smelting industry, the southwestern and central-southern provinces also play a prominent role in HM emissions.

The overall uncertainties in our bottom-up inventories are thought to be reasonable and acceptable with the adequate data availability. Nevertheless, to achieve more reliable estimations of HM emissions in China, much more detailed investigations and long-term field tests for all kinds of coalfired facilities and industrial processes are still greatly needed in the future.

\section{The Supplement related to this article is available online at doi:10.5194/acp-15-10127-2015-supplement.}

Acknowledgements. This work is funded by the National Natural Science Foundation of China (21177012, 21377012 and 40975061), the Special Program on Public Welfare of the Ministry of Environmental Protection (201409022), Open fund of State Environmental Protection Key Laboratory of Sources and Control of Air Pollution Complex (SCAPC201305), and the special fund of State Key Joint Laboratory of Environmental Simulation and Pollution Control (13L02ESPC). We thank Tami Bond and Freed Chuck for their help in improving the English writing in this paper.

Edited by: T. Bond

\section{References}

Akimoto, H., Ohara, T., Kurokawa, J, and Horii, N.: Verification of energy consumption in China during 1996-2003 by using satellite observational data, Atmos. Environ., 40, 7664-7667, doi:10.1016/j.atmosenv.2006.07.052, 2006.

Annema, J. A.: SPIN document "Productie van secundair staal", RIVM rapportnr, the Netherlands, 1993.

Biggins, P. D. and Harrison, R. M.: Atmospheric chemistry of automotive lead, Environ. Sci. Technol., 13, 558-565, doi:10.1021/es60153a017, 1979.

Bond, T. C., Bhardwaj, E., Dong, R., Jogani, R., Jung, S., Roden, C., Streets, D. G., and Trautmann, N. M.: Historical emissions of black and organic carbon aerosol from energy related combustion, 1850-2000, Global Biogeochem. Cy., 21, 1-16, doi:10.1029/2006GB002840, 2007.

Bukowiecki, N., Lienemann, P., Hill, M., Figi, R., Richard, A., Furger, M., Rickers, K., Falkenberg, G., Zhao, Y., and Cliff, S. S.: Real-world emission factors for antimony and other brake wear related trace elements: size-segregated values for light and heavy duty vehicles, Environ. Sci. Technol., 43, 8072-8078, doi:10.1021/es9006096, 2009.
Chang, M. B., Huang, C. K., Wu, H. T., Lin, J. J., and Chang, S. H.: Characteristics of heavy metals on particles with different sizes from municipal solid waste incineration, J. Hazard. Mater., 79, 229-239, doi:10.1016/S0304-3894(00)00277-6, 2000.

Cheng, H. F. and Hu, Y. A.: Municipal solid waste (MSW) as a renewable source of energy: Current and future practices in China, Bioresour. Technol., 101, 3816-3824, doi:10.1016/j.biortech.2010.01.040, 2010.

Cheng, K., Wang, Y., Tian, H. Z., Gao, X., Zhang, Y. X., Wu, X. C., Zhu, C. Y., and Gao, J. J.: Atmospheric emission characteristics and control policies of five precedent-controlled toxic heavy metals from anthropogenic sources in China, Environ. Sci. Technol., 49, 1206-1214, doi:10.1021/es5037332, 2015.

Cheng, Z., Wang, S., Fu, X., Watson, J. G., Jiang, J., Fu, Q., Chen, C., Xu, B., Yu, J., Chow, J. C., and Hao, J.: Impact of biomass burning on haze pollution in the Yangtze River delta, China: a case study in summer 2011, Atmos. Chem. Phys., 14, 45734585, doi:10.5194/acp-14-4573-2014, 2014.

China Iron and Steel Association (CISA), P. R. China: China Steel Yearbook, China Steel Industry Press, Beijing, 2013 (in Chinese).

China Machinery Industry Federation (CMIF), P. R. China: China Machinery Industry Yearbook, China Machine Press, Beijing, 2013.

Department of Environment of Australia (DEA): Emissions estimation technique manual for aggregated emissions from domestic solid fuel burning, National Pollutant Inventroy (NPI), 1999.

Duan, J. C. and Tan, J. H.: Atmospheric heavy metals and arsenic in China: situation, sources and control policies, Atmos. Environ., 74, 93-101, doi:10.1016/j.atmosenv.2013.03.031, 2013.

European Commission (EC): Integrated Pollution Prevention and Control (IPPC), Best available techniques reference document on the production of iron and steel, 2001.

European Environment Agency (EEA): EMEP/EEA air pollutant emission inventory guidebook 2009, available at: http://www.eea.europa.eu/publications/ emep-eea-emission-inventory-guidebook-2009 (last access: 24 December 2013), 2009.

European Environment Agency (EEA): EMEP/EEA air pollutant emission inventory guidebook 2013, available at: http://www. eea.europa.eu/publications/emep-eea-guidebook-2013 (last access: 12 November 2013), 2013.

Fang, F. M., Wang, Q. C., Ma, Z. W., Liu, R. H., and Cao, Y. H.: Estimation of atmospheric input of mercury to South Lake and Jingyue Pool, Chinese Geog. Sci., 12, 86-89, doi:10.1007/s11769-002-0076-y, 2002.

Feng, X.: Mercury pollution in China - an overview, Springer Publishers, 657-678, doi:10.1007/0-387-24494-8_27, 2005.

Gao, J. J., Tian, H. Z., Cheng, K., Lu, L., Wang, Y. X., Wu, Y., Zhu, C. Y., Liu, K. Y., Zhou, J. J., Liu, X. G., Chen, J., and Hao, J. M.: Seasonal and spatial variation of trace elements in multisize airborne particulate matters of Beijing, China: Mass concentration, enrichment characteristics, source apportionment, chemical speciation and bioavailability, Atmos. Environ., 99, 257-265, doi:10.1016/j.atmosenv.2014.08.081, 2014.

Grübler, A., Nakićenović, N., and Victor, D. G.: Dynamics of energy technologies and global change, Energy Policy, 27, 247280, doi:10.1016/S0301-4215(98)00067-6, 1999. 
Hao, J. M., Tian, H. Z., and Lu, Y. Q.: Emission inventories of NOx from commercial energy consumption in China, 1995-1998, Environ. Sci. Technol., 36, 552-560, doi:10.1021/es015601k, 2002.

Hassel, D., Jost, P., and Dursbeck, F.: Das AbgasEmissionsverhalten von Personenkraftwagen in der Bundesrepublik Deutschland im Bezugsjahr, 1985, UBA-Berichte, 7, 1987.

Hjortenkrans, D. S., Bergbäck, B. G., and Häggerud, A. V.: Metal emissions from brake linings and tires: case studies of Stockholm, Sweden 1995/1998 and 2005, Environ. Sci. Technol., 41, 5224-5230, doi:10.1021/es070198o, 2007.

Hulskotte, J. H. J., Schaap, M., and Visschedijk, A. J. H.: Brake wear from vehicles as an important source of diffuse copper pollution, 10th International specialized conference on diffuse pollution and sustainable basin management, 18-22, 2006.

Industrial emissions Reporting Information System (IRIS), European Commission, available at: http://iris.eionet.europa.eu/ippc/ reporting-period-2003-2005/elv-reports/key-results/ (last access: 18 September 2014), 2005.

International Agency for Research on Cancer (IARC): Agents classified by the iarc monographs, volumes $1-111$, available at: http://monographs.iarc.fr/ENG/Classification/index.php (last access: 23 October 2014), 2014.

Jockel, W. and Hartje, J.: Datenerhebung Ÿber die emissionen umweltgefŠhrdender schwermetalle, forschungsbericht 91-104 02 588, T V Rheinland e.V. Köln, 1991.

Johansson, C., Norman, M., and Burman, L.: Road traffic emission factors for heavy metals, Atmos. Environ., 43, 4681-4688, doi:10.1016/j.atmosenv.2008.10.024, 2009.

Kavlak, G. and Graedel, T. E.: Global anthropogenic selenium cycles for 1949-2010, Resour. Conserv. Recycl., 73, 17-22, doi:10.1016/j.resconrec.2013.01.013, 2013.

Kung, J. K. S. and Lin, J. Y.: The Causes of China's Great Leap Famine, 1959-1961, Econ. Dev. Cultural Change, 52, 51-73, doi:10.1086/380584, 2003.

Li, J. F., Song, Y., Mao, Y., Mao, Z. C., Wu, Y. S., Li, M. M., Huang, X., He, Q. C., and Hu, M.: Chemical characteristics and source apportionment of PM2.5 during the harvest season in eastern China's agricultural regions, Atmos. Environ., 92, 442-448, doi:10.1016/j.atmosenv.2014.04.058, 2014.

Lu, B., Kong, S. F., Han, B., Wang, X. Y., and Bai, Z. P.: Inventory of atmospheric pollutants discharged from biomass burning in China continent in 2007, Chin. Environ. Sci., 31, 186-194, 2011 (In Chinese with English abstract).

Ministry of Environmental Protection of the People's Republic of China (MEP), P. R. China: Emission standard of air pollutants for iron smelt industry, Beijing, 2012 (in Chinese).

Ministry of Environmental Protection of the People's Republic of China (MEP), P. R. China: The list of desulfurization facilities equipped by coal-fired boiler in China, available at: http://www.mep.gov.cn/gkml/hbb/bgg/201407/ W020140711581927228220.pdf (last access: 8 July 2014), 2014a.

Ministry of Environmental Protection of the People's Republic of China (MEP), P. R. China: The list of denitration facilities equipped by coal-fired boiler in China, available at: http://www.mep.gov.cn/gkml/hbb/bgg/201407/ W020140711581927393439.pdf (last access: 8 July 2014), $2014 b$.
Mukherjee, A. B.: Nickel: a review of occurrence, uses, emissions, and concentration in the environment in Finland, Environ. Rev., 6, 173-187, doi:10.1139/a99-001, 1998.

National Bureau of Statistics (NBS), P. R. China: Report on "12th Five-Year Plan" of the electric power industry. National Bureau of Statistics of China, Beijing, China, 2011 (in Chinese).

National Bureau of Statistics (NBS), P. R. China: China Energy Statistical Yearbook, China Statistics Press, Beijing, 2013b.

National Bureau of Statistics (NBS), P. R. China: China Statistical Yearbook, China Statistics Press, Beijing, 2013a.

Nie, Y. F.: Development and prospects of municipal solid waste (MSW) incineration in China, Front. Environ. Sci. Engin. China, 2, 1-7, doi:10.1007/s11783-008-0028-6, 2008.

Nriagu, J. O.: Global inventory of natural and anthropogenic emissions of trace metals to the atmosphere, Nature, 279, 409-411, doi:10.1038/279409a0, 1979.

Nriagu, J. O. and Pacyna, J. M.: Quantitative assessment of worldwide contamination of air, water and soils by trace metals, Nature, 333, 134-139, doi:10.1038/333134a0, 1988.

Österle, W., Prietzel, C., Kloß, H., and Dmitriev, A. I.: On the role of copper in brake friction materials, Tribol. Int., 43, 2317-2326, doi:10.1016/j.triboint.2010.08.005, 2010.

Pacyna, E. G., Pacyna, J. M., Steenhuisen, F., and Wilson, S.: Global anthropogenic mercury emission inventory for 2000, Atmos. Environ., 40, 4048-4063, doi:10.1016/j.atmosenv.2006.03.041, doi:10.1016/j.atmosenv.2006.03.041, 2006.

Pacyna, J. M.: Estimation of the atmospheric emissoins of trace elements from anthropogenic sources in Europe, Atmos. Environ., 18, 41-50, doi:10.1016/0004-6981(84)90227-0, 1984.

Pacyna, J. M. and Pacyna, E. G.: An assessment of global and regional emissions of trace metals to the atmosphere from anthropogenic sources worldwide, Environ. Rev., 9, 269-298, doi:10.1139/a01-012, 2001.

Pirrone, N., Cinnirella, S., Feng, X., Finkelman, R. B., Friedli, H. R., Leaner, J., Mason, R., Mukherjee, A. B., Stracher, G. B., Streets, D. G., and Telmer, K.: Global mercury emissions to the atmosphere from anthropogenic and natural sources, Atmos. Chem. Phys., 10, 5951-5964, doi:10.5194/acp-10-59512010, 2010.

Qin, J. F.: Estimation of lead emission to atmospheric from gasoline combustion, Guangdong Trace Ele. Sci., 17, 27-34, 2010 (in Chinese).

Reddy, M. S., Basha, S., Joshi, H. V., and Jha, B.: Evaluation of the emission characteristics of trace metals from coal and fuel oil fired power plants and their fate during combustion, J. Hazard. Mater., 123, 242-249, doi:10.1016/j.jhazmat.2005.04.008, 2005.

Ren, D. Y., Zhao, F. H., Dai, S., and Zhang, J.: Geochemistry of trace elements in coal, Science Press, Beijing, 2006 (in Chinese).

Robbins, N., Zhang, Z. F., Sun, J., Ketterer, M. E., Lalumandier, J. A., and Shulze, R. A.: Childhood lead exposure and uptake in teeth in the Cleveland area during the era of leaded gasoline, Sci. Total Environ., 408, 4118-4127, doi:10.1016/j.scitotenv.2010.04.060, 2010.

Song, D. Y., Qin, Y., and Wang, W. F.: Burning and migration behavior of trace elements of coal used in power plant, J. China Univ. Min. Technol., 32, 316-320, 2003 (in Chinese with English abstract). 
Streets, D. G., Bond, T. C., Lee, T., and Jang, C.: On the future of carbonaceous aerosol emissions, J. Geophys. Res., 109, 1-19, doi:10.1029/2004JD004902, 2004.

Streets, D. G., Bond, T. C., Carmichael, G. R., Fernandes, S. D., and $\mathrm{Fu}, \mathrm{Q}$.: An inventory of gaseous and primary aerosol emissions in Asia in the year 2000, J. Geophys. Res. Policy, 108, 8809, doi:10.1029/2002JD003093, 2003.

Streets, D. G., Hao, J. M., Wu, Y., Jiang, J. K., Chan, M., Tian, H. Z., and Feng, X. B.: Anthropogenic mercury emissions in China, Atmos. Environ., 39, 7789-7806, doi:10.1016/j.atmosenv.2005.08.029, 2005.

Streets, D. G., Devane, M. K., Lu, Z., Bond, T. C., Sunderland, E. M., and Jacob, D. J.: All-time releases of mercury to the atmosphere from human activities, Environ. Sci. Technol., 45, 1048510491, doi:10.1021/es202765m, 2011.

Tang, X. Y., Zhao, J. Y., and Huang, W. H.: Nine metal elements in coal of China, Coal Geol. China, 14, 43-54, 2002 (in Chinese).

Theloke, J., Kummer, U., Nitter, S., Geftler, T., and Friedrich, R.: Überarbeitung der Schwermetallkapitel im CORINAIR Guidebook zur Verbesserung der Emissionsinventare und der Berichterstattung im Rahmen der Genfer Luftreinhaltekonvention. Report for Umweltbundesamt, 2008.

Tian, H. Z., Hao, J. M., Hu, M. Y., and Nie, Y. F.: Recent trends of energy consumption and air pollution in China, J. Energy Eng., 133, 4-12, doi:10.1061/(ASCE)0733-9402(2007)133:1(4), 2007.

Tian, H. Z., Wang, Y., Xue, Z. G., Cheng, K., Qu, Y. P., Chai, F. H., and Hao, J. M.: Trend and characteristics of atmospheric emissions of $\mathrm{Hg}$, As, and Se from coal combustion in China, 19802007, Atmos. Chem. Phys., 10, 11905-11919, doi:10.5194/acp10-11905-2010, 2010.

Tian, H. Z., Cheng, K., Wang, Y., Zhao, D., Chai, F. H., Xue, Z. G., and Hao, J. M.: Quantitative assessment of variability and uncertainty of hazardous trace element $(\mathrm{Cd}, \mathrm{Cr}$, and $\mathrm{Pb})$ contents in Chinese coals by using bootstrap simulation, J. Air Waste Manage. Assoc., 61, 755-763, doi:10.3155/1047-3289.61.7.755, 2011a.

Tian, H. Z., Zhao, D., and Wang, Y.: Emission inventories of atmospheric pollutants discharged from biom ass burning in China, Acta Sci. Circumstantiae, 31, 349-357, 2011 b (in Chinese with English abstract).

Tian, H. Z., Cheng, K., Wang, Y., Zhao, D., Lu, L., Jia, W. X., and Hao, J. M.: Temporal and spatial variation characteristics of atmospheric emissions of $\mathrm{Cd}, \mathrm{Cr}$, and $\mathrm{Pb}$ from coal in China, Atmos. Environ., 50, 157-163, doi:10.1016/j.atmosenv.2011.12.045, 2012a.

Tian, H. Z., Lu, L., Cheng, K., Hao, J. M., Zhao, D., Wang, Y., Jia, W. X., and Qiu, P. P.: Anthropogenic atmospheric nickel emissions and its distribution characteristics in China, Sci. Total Environ., 417, 148-157, doi:10.1016/j.scitotenv.2011.11.069, 2012b.

Tian, H. Z., Zhao, D., Cheng, K., Lu, L., He, M. C., and Hao, J. M.: Anthropogenic atmospheric emissions of antimony and its spatial distribution characteristics in China, Environ. Sci. Technol., 46, 3973-3980, doi:10.1021/es2041465, 2012c.

Tian, H. Z., Gao, J. J., Lu, L., Zhao, D., Cheng, K., and Qiu, P. P.: Temporal trends and spatial variation characteristics of hazardous air pollutant emission inventory from municipal solid waste incineration in China, Environ. Sci. Technol., 46, 1036410371, doi:10.1021/es302343s, 2012d.
Tian, H., Lu, L., Hao, J. M., Gao, J. J., Cheng, K., Liu, K. Y., Qiu, P. P., and Zhu, C. Y.: A review of key hazardous trace elements in Chinese coals: Abundance, occurrence, behavior during coal combustion and their environmental impacts, Energy Fuels, 27, 601-614, doi:10.1021/ef3017305, 2013.

Tian, H., Liu, K. Y., Zhou, J. J., Lu, L., Hao, J. M., Qiu, P. P., Gao, J. J., Zhu, C. Y., Wang, K., and Hua, S. B.: Atmospheric emission inventory of hazardous trace elements from China's coal-fired power plants-Temporal trends and spatial variation characteristics, Environ. Sci. Technol., 48, 3575-3582, doi:10.1021/es404730j, 2014a.

Tian, H. Z., Zhou, J. R., Zhu, C. Y., Zhao, D., Gao, J. J., Hao, J. M., He, M. C., Liu, K. Y., Wang, K., and Hua, S. B.: A Comprehensive global inventory of atmospheric antimony emissions from anthropogenic activities, 1995-2010, Environ. Sci. Technol., 48, 10235-10241, doi:10.1021/es405817u, 2014b.

United Kingdom (UK): emission factor databases of NAEI, 1970-1995, availiable at: http://naei.defra.gov.uk/data/ ef-all-resultsfiq=14774, (last access: 10 August 2014), 1995.

United Kingdom (UK): emission factor databases of NAEI, available at: http://naei.defra.gov.uk/data/ef-all-resultsfiq=15354 (last access: 11 September 2014), 2012.

US Environmental Protection Agency (US EPA): AP 42, fifth edition, volume I, chapter 1, section 1.1: bituminous and subbituminous coal combustion, availabe at: http://www.epa.gov/ttn/chief/ ap42/ch01/index.html (last access: 12 October 2014), 1993.

US Environmental Protection Agency (US EPA): AP 42, fifth edition, volume I, chapter 2, section 2.1: refuese combustion, availiable at: http://www.epa.gov/ttn/chief/ap42/ch02/index.html (last access: 23 July 2014), 1996.

US Environmental Protection Agency (US EPA): Web Factor Information Retrieval System (WebFIRE), availabe at: $\quad$ http://cfpub.epa.gov/webfire/index.cfmfiaction=fire. FactorsBasedOnDetailedSearch (last access: 21 September 2014), 2012.

Van der Most, P. F. J. and Veldt, C.: Emission factors Manual PARCOM-ATMOS, TNO-MEP, Apeldoorn, the Netherlands, 1991.

von Uexküll, O., Skerfving, S., Doyle, R., and Braungart, M.: Antimony in brake pads-a carcinogenic componentfi, J. Cleaner Prod., 13, 19-31, doi:10.1016/j.jclepro.2003.10.008, 2005.

Wu, Q. R., Wang, S. X., Zhang, L., Song, J. X., Yang, H., and Meng, Y.: Update of mercury emissions from China's primary zinc, lead and copper smelters, 2000-2010, Atmos. Chem. Phys., 12, 11153-11163, doi:10.5194/acp-12-11153-2012, 2012.

Wu, Y., Wang, S. X., Streets, D. G., Hao, J. M., Chan, M., and Jiang, J. K.: Trends in anthropogenic mercury emissions in China from 1995 to 2003, Environ. Sci. Technol., 40, 5312-5318, doi:10.1021/es060406x, 2006.

Wu, Y. Y., Qin, Y., Yi, T. S., and Xia, X. H.: Enrichment and geochemical origin of some trace elements in high-sulfur coal from Kaili, eastern Guizhou Province, Geochimica, 37, 615-622, 2008 (in Chinese with English abstract).

Wu, Y., Streets, D. G., Wang, S. X., and Hao, J. M.: Uncertainties in estimating mercury emissions from coal-fired power plants in China, Atmos. Chem. Phys., 10, 2937-2946, doi:10.5194/acp10-2937-2010, 2010.

Xu, H. M., Cao, J. J., Ho, K. F., Ding, H., Han, Y. M., Wang, G. H., Chow, J. C., Watson, J. G., Khol, S. D., Qiang, J., and Li, W. T.: 
Lead concentrations in fine particulate matter after the phasing out of leaded gasoline in Xi' an, China, Atmos. Environ., 46, 217224, doi:10.1016/j.atmosenv.2011.09.078, 2012.

Xu, M. H., Yan, R., Zheng, C. G., Qiao, Y., Han, J., and Sheng, C. D.: Status of trace element emission in a coal combustion process: a review, Fuel Process. Technol., 85, 215-223, doi:10.1016/S0378-3820(03)00174-7, 2004.

Yuan, X. L., Mi, M., Mu, R. M., and Zuo, J.: Strategic route map of sulphur dioxide reduction in China, Energy Policy, 60, 844-851, doi:10.1016/j.enpol.2013.05.072, 2013.

Zhang, J. L. and Wang, G. S.: Energy saving technologies and productive efficiency in the Chinese iron and steel sector, Energy, 33, 525-537, doi:10.1016/j.energy.2007.11.002, 2008.
Zhao, Y., Nielsen, C. P., Lei, Y., McElroy, M. B., and Hao, J.: Quantifying the uncertainties of a bottom-up emission inventory of anthropogenic atmospheric pollutants in China, Atmos. Chem. Phys., 11, 2295-2308, doi:10.5194/acp-11-2295-2011, 2011.

Zhu, C. Y., Tian, H. Z., Cheng, K., Liu, K. Y., Wang, K., Hua, S. B., Gao, J. J., and Zhou, J. R.: Potentials of whole process control of heavy metals emissions from coal-fired power plants in China, J. Cleaner Prod., doi:10.1016/j.jclepro.2015.05.008, in press, 2015. 